\title{
Lessons from a global remote sensing mapping project. A review of the impact of the Millennium Coral Reef Mapping Project for science and management
}

\author{
Andréfouët S. ${ }^{1,{ }^{*}}$, Bionaz O. ${ }^{1,2}$
}

\begin{abstract}
${ }^{1}$ Institut de Recherche pour le Développement - France, UMR 9220 Entropie (Institut de Recherche pour le Développement - France, Université de la Réunion, Université de la Nouvelle-Calédonie, Ifremer, Centre National de la Recherche Scientifique), BP A5, 98848 Nouméa, Cedex, New Caledonia 2 Université de la Rochelle, France

*Corresponding author : S. Andréfouët, emai laddress : serge.andrefouet@ird.fr
\end{abstract}

\begin{abstract}
:
Anthropogenic and natural impacts threaten the sustainability of ecosystem services provided by the ocean and its coastlines. Coral reefs are an endangered and important component of the tropical realm. Coral reef science, management and conservation programs greatly benefit from habitat maps when they are available. This study reviews the use of the Millennium Coral Reef Mapping Project (MCRMP), which hierarchically mapped since 2004 coral reefs worldwide using Landsat satellite multispectral imagery at 30 meter spatial resolution. Tracking in the scientific literature the impact of MCRMP products proved to be difficult because of frequent lack of citations (omission errors) and confusion with products that have integrated MCRMP data but degraded them (commission errors). To categorize the applications themes, we selected 62 representative studies that unambiguously used MCRMP products. MCRMP products were used prominently to achieve new results in coral reef inventories; conservation planning; enhancement of biodiversity and fishery resource mapping, monitoring and modeling; connectivity and climate change modeling. The products were also useful to map other ecosystems. We evaluate the main strengths, weaknesses, opportunities, and threats to MCRMP products. From this review, we also make recommendations and reflect more generally on the value of future global-scale mapping projects targeting specific ecosystems.
\end{abstract}




\section{Graphical abstract}

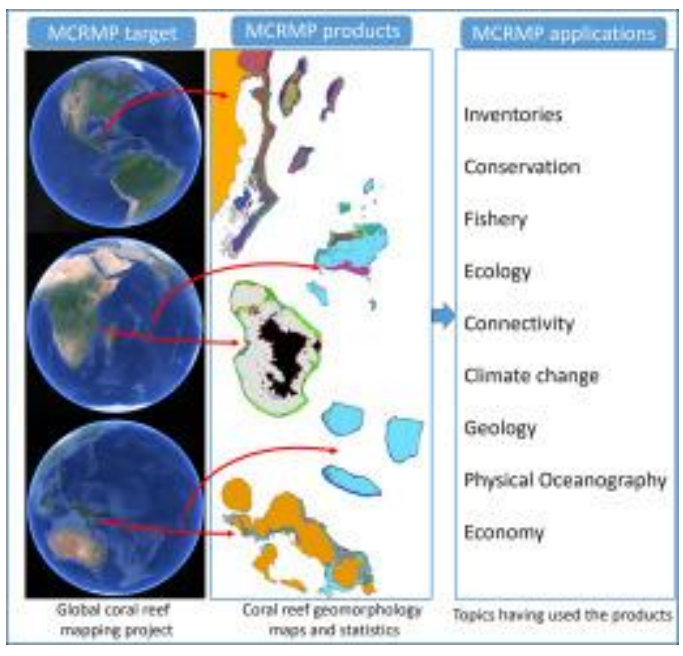

\section{Highlights}

- The impact of the Millennium Coral Reef Mapping Project (MCRMP) is reviewed $>$ It was the first remote sensing project that targeted coral reefs globally - MCRMP has created since 2004 hierarchical maps of coral reefs worldwide using Landsat - Examples of inventories, conservation, fishery, climate and ecology applications are discussed - Lessons from MCRMP can be useful for future global projects

Keywords : conservation, fishery, climate change, habitat mapping 


\section{Introduction}

Over the last decades, human population and infrastructure development have grown exponentially. The increasing global demand for natural resources, unsustainable pressures on marine ecosystems and climate change impacting the Biosphere have led to the so-called Anthropocene era, a new geological epoch defined by the marked influence of humans (Lewis and Maslin 2015). In particular, marine biodiversity and ecosystems are increasingly suffering from pollution, mineral extraction, fishing, overexploitation and rising atmospheric 
carbon dioxide levels $\left(\mathrm{CO}_{2}\right)$ which results in an increase of ocean temperature and acidity (Doney et al. 2012) and from the complex interactions of all these disturbances,

Tropical human societies depend on healthy marine and coastal environmental that can provide a large range of ecosystem services such as materials, carbon regulation, food resources and fisheries, and physical protection. This is notably the case for coral reefs, seagrass, and mangroves (Doney et al. 2012). With the intensifying threats, countless conservation initiatives have increased their focus on these ecosystems especially in the past 20 years. These initiatives require and use a variety of integrated socio-ecosystem metrics and indicators to describe conservation status, targets, and measures. On the biological side of these metrics, biological diversity, species distribution, populatı? size and condition, habitat distribution, extent and condition, and ecosystem structure are all :ritical information.

Habitat mapping is an important component of managem 'nt : nd conservation strategies and programs (Turner et al. 2003, Kachelriess et al. 2n(-) Habitat maps can inform these programs in many ways, for instance to facilita participatory workshops involving stakeholders, design field-based sampling protr 0 . $s$ identify remarkable zones, or delineate management planning units (Van Wynsbergc at a1. 2015). The design of many conservation programs has benefited from the incı as $\mathrm{d}$ availability of habitat maps for mangroves, seagrass meadows and coral reefs, dc nite the many gaps still left (Purkis 2018, Wang et al. 2019, Veettil et al. 2020).

If we focus on coral reefs, back in th Iate 1990s and early 2000s, strong emphasis was put by managers on simply knowing how much coral reef areas existed, and where, globally, nationally and locally (Sp.ldir $\mathrm{g}$ et al; 2001). Consistent inventories was a management priority. This was befor $\mathrm{mc}$ e complex analysis on a variety of processes could be tackled. Today, the focus and per seived important gaps may be different, but habitat maps are still needed to understand better and mitigate the effects of intensive fishing, climate change, pelagic and benthic mortalities, sea level rise, increased frequencies of extreme events such as cyclones, and all other natural and human-induced stressors (Hamylton 2017, El Mahrad et al. 2020). In 2002, to respond to the rising demand for accurate coverage statistics, maps, and to foster spatially-explicit coral reef studies, the Oceanography Program of the National Aeronautics and Space Administration (NASA), funded the Institute for Marine Remote Sensing (IMaRS) at University of South Florida to launch the Millennium Coral Reef Mapping Project (MCRMP) and distribute the products. The project was also further funded by Institut de Recherche pour le Développement (IRD) by mid-2003 through in kind contribution. Throughout the subsequent years, the objective remained to move forward 
towards a consistent cartographic product of coral reefs worldwide and to distribute these products as Geographical Information System (GIS) layers to help coral reef science and management initiatives (Andréfouët et al. 2006). After 2008, however, the creation of new products became more project-oriented, and on-request, instead of filling gaps systematically. The primary aim of this literature review was to assess for which science and management application MCRMP products have been useful, nearly 20 years after the initial funding was awarded. From this assessment, it is possible to discuss if MCRMP met its objectives, and in which field in particular. It is also possible to discuss if the products were adequately used or not. Finally, the review can also highlight in the case of future similar niche global-scale mapping projects that focus on specific ecosystems i) if they aic really needed, compared to more local projects, and ii) if some lessons can be learnt from the MCRMP project.

\section{Background on MCRMP and Methods \\ The context of remote sensing of coral reefs in the ear, $2000 \mathrm{~s}$}

At the time of the genesis of the MCRMP project, $n$ ive early 2000s, an intense period of

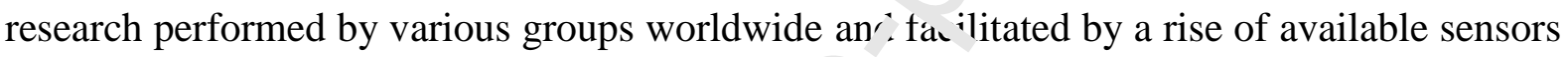
had recently clarified what was possible using $r \cdot r_{10}$ e sensing for coral reef investigation and for coral reef habitat mapping in particul _. A A Aréfouët and Riegl 2004). Several key simple facts valid 20 years ago (many still re vant today, Kutser et al. 2020) need to be reemphasized, because they conditioned ${ }_{1}{ }^{\top} \mathrm{CRMP}$. We list them as bullet points.

- The extent of coral reefs was stilı i nr recise at national and international scales, and better, more consistent, inventories $w$ re needed in priority (Spalding et al. 2001).

- Coral reef habitats globali, ca: be described with geomorphological (continental/oceanic, reef forms, depth, etc' anc 'senthic (cover, architecture, rugosity, species, etc.) attributes (Andréfouët et al. ¿१)

- Accuracy of habitat $\sim$ aps is highly variable. The mapping of geomorphological attributes is more accurate than benthic attributes (Andréfouët et al. 2003, NOAA 2003).

- While spectral signatures (i.e., the reflectance spectra of an object, or the variation of reflected light as a function of wavelength) can be differentiated at small (organism) spatial scales (Hochberg et al. 2003), spatial mixing of benthic organisms on reefs complicate the detection of individual components of reef benthos. When depth increases, even for spectrally distinct features such as bleached corals, the discrimination of individual submerged objects is even more very limited, (Andréfouët et al. 2002; Hedley et al. 2012).

- Although managers often focus on the live coral cover index as a measure of reef health, 
mapping live coral cover basically remains an utopia when using remote sensing, except when very specific conditions (homogeneous cover, clear water, shallow depth) and high resolution sensing capacities can be met (Hedley et al. 2012).

- Field-based accuracy assessment can be easily and optimistically affected by a biased control sampling (Andréfouët 2008), but it is a necessary evil in order to trust the quality of any maps (Foody 2002). Geomorphological maps do not require ground-truthing because class boundaries are fairly obvious, but the interpretation of geomorphology (labelling) may vary (Andréfouët et al. 2006).

- High mapped geomorphological richness, as a proxy of habitat richness, could be linked to high species diversity (Andréfouët and Guzman 2005).

- Image processing methods for habitat mapping are m.ltirle, but the most efficient combine a mix of spectral, spatial, and contextual e $e^{\prime}$ itin s approaches, the latter being particularly effective for geomorphological mappir。'A.dréfouët 2008).

- In 2000, only the Landsat 7 Enhanced Thematic $\mathbf{M} \mathbf{c}_{1} \cdot$ oer Plus (ETM+) mission, providing $30 \mathrm{~m}$ resolution multispectral images, had la.1 a systematic acquisition of coral reefs,

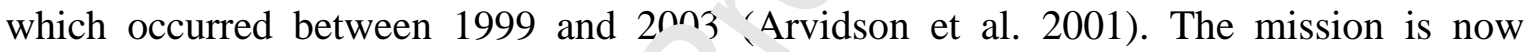
continued with Landsat 8 since 2013. 'Try high spatial resolution (1-4m) multispectral (48 bands) images became increasit ${ }_{e}^{-1} y$ available starting in the early 2000s, and quickly became the most common sourc $r t$ Lata for local coral reef mapping, but they remained expensive for large areas. Nc vaanys, in 2020, 10m-resolution data are available for free, almost globally, with the Sel ${ }^{-i n e l}-2$ mission, and $3.7 \mathrm{~m}$ resolution Planet archived data cost start at about $1.5-2 \$ . \mathrm{km}^{?}$

From these key-poir`‘, iven y years ago, an innovative, valuable, cost-effective, consistent, first global mapping of ( oral reefs could be feasible only by 1) using Landsat satellite; 2) avoiding costly ground-truthing; 3) mapping geomorphological entities compatible with Landsat spatial resolution, 4) maximizing the geomorphological thematic richness globally to offer a maximum of potential application for biodiversity applications: 5) mapping consistently between locations, with the same classification scheme, the same methods and the same trained mapping team familiar with coral reefs (Andréfouët et al. 2006).

\section{MCRMP products}

MCRMP mapping products describe coral reef geomorphological units, which provides a first level of habitat description and definition. They are created by using cloud-free Landsat 7 remote sensing images. These images have a spatial resolution of $30 \mathrm{~m}$, and 4 of the 7 spectral bands were used for MCRMP (blue, green, red, and near-infra-red). Images used by 
MCRMP were acquired from 1999 to 2003 . After a period of trials, it was decided that to be able to use the maps universally and for different applications, coral reefs could be classified geomorphologically into five hierarchical levels of thematic resolution. Level 1 - the simplest - corresponds to the differentiation between oceanic and continental (shelf) reefs. Then from Levels 2 to 5 , the higher the level, the more detailed the classification is. To illustrate this hierarchical typology, Figure 1 shows examples of maps for Levels 3, 4 and 5 for Huahine, a high oceanic island in French Polynesia. Huahine is an Oceanic (Level 1) Island (Level 2). At Level 3, it includes several geomorphological reef entities such as 'outer barrier reef', 'coastal barrier reef', 'oceanic exposed fringing reef', and 'lagoon-exposed fringing reef'. We note that Level 4 provides a separate catalogue of coral ree ${ }_{1}$ reomorphological structures than can be present in each of the Level 3 structures. For inst. nce the Level 4 class 'forereef' (Figure 1, middle) can be found either in the Level 3 'ou' $r$ b rrier reef complex' class or in the Level 3 'coastal barrier reef complex' class (Figure ! top). Level 5, the most complex level, combines the levels 1 to 4 . As such, the Leve, 5 lass: 'reef flat' (L4) of an 'oceanic exposed fringing reef' (L3) of a 'island' (L2) 'o ec nic' (L1) is different from the 'reef flat' of an 'oceanic exposed fringing reef' of a 'isla. 1 ' 'continental'. Similarly, the 'reef flat' of an 'oceanic exposed fringing reef' of a 'islu. 'd' 'oceanic' (cf. code '224' in Figure 1) is different at Level 5 from the 'forereef' of an 'croanic exposed fringing reef' of a 'island' 'oceanic' (cf. code ' 222 ' in Figure 1).

All polygons are also described $1, y_{\sim} \cdot v e r a l$ attributes that indicate if they are part of the land

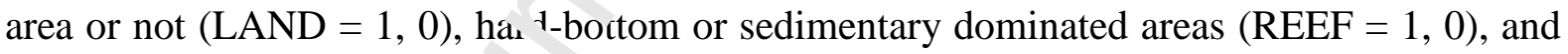
provide a qualitative indica: inn wi depth.

Overall, a total of $805 \mathrm{~L}$ vel 5 classes are defined for all coral reefs worldwide. However, not all classes occur in a s. ngle location (Andréfouët et al. 2006). A complex island like Huahine has 19 Level 5 entities, not 805 (Figure 1). It is important to reemphasize that MCRMP products do not necessitate ground-truth data for the identification of geomorphological classes. This is a real advantage, and a necessity, for the feasibility of a global mapping project with limited budget.

A very important point is that MCRMP products target applications preferentially at a regional meso-scale. In other words, they are not suitable for small-scale (e.g. $<1 \mathrm{~km}^{2}$ ) studies, but rather for larger areas (i.e. > $100 \mathrm{~km}^{2}$ ), thus encompassing large islands, archipelagos, and zones up to the scale of nations or regions. To date, most coral reef regions have Level 1-5 products at national scales, but gaps still remain, namely for the Red Sea (no product) and Indonesia-Philippines which are partially mapped at Level 3 only. Several 
previous products have also not been updated using the current classification scheme and codes (most recent version from 2012).

Since 2006, MCRMP products have been integrated in other coral reef map databases, notably in the UNEP World Conservation Monitoring Centre (UNEP-WCMC) database (available here: https://data.unep-wcmc.org/datasets/1). The UNEP-WCMC compiled coral reef data from MCRMP and from the previous World Atlas of Coral Reefs (Spalding et al. 2001), as well as several other sources for specific locations. It provides a global coverage. However, it should be made very clear that UNEP-WCMC products only provide a singleattribute reef layer, without any geomorphological or depth attributes or any classification of types of coral reefs as they are found on MCRMP data. In other vords, all reefs are the same. Furthermore, in agreement with NASA and IMaRS, UNEP- VC $1 \mathrm{C}$ integrated after its own interpretation a number of non-validated MCRMP proc icts which is the reason why the product is not endorsed by IRD. This integration allnrrec. increasing the spatial coverage of the product but resulted in a number of problems $\iota^{*}$., duplicate polygons, deletion of in particular fringing reef areas, inconsistent reint sf etation of several features, etc.). Some of these problems were detected and describit tor instance by Cros et al. (2014) when themselves integrated these products $i_{1}{ }^{+} \mathrm{o}$ another database (Coral Triangle Atlas). Since 2008, no other MCRMP products huve been added to the UNEP-WCMC database to our knowledge and products updated an $\uparrow_{\ldots}$ al $_{1 \text { ized }}$ after 2008 are available on request to IRD.

Another product integrated MCR Mi vata, namely the Reef at Risk/World Resources Institute (WRI) Caribbean coral reef layer (Burke and Maidens 2004). This product includes resampled Caribbean MCГMP products (those available in 2004) at 500 meter resolution. The WRI product mer es arious data sources (MCRMP, NOAA, UNEP-WCMC) as a binary product without hl rarchical levels of description.

\section{Scientific literature search}

A literature search was conducted through the SCOPUS, Google Scholar and Web of Science (WOS) databases for articles citing the initial article presenting the MCRMP (Andréfouët et al. 2006) or containing 'Millennium Coral Reefs Mapping Project'. For instance, according to Google Scholar, 254 papers and reports cite the initial article (as of 18/01/2021). The Reefbase library (http://www.reefbase.org) was also searched as it includes coral reef conference proceedings. Papers cited by the identified references were also scrutinized to identify grey literature reports that are more difficult to find. Often, the Principal Investigator of the MCRMP project was involved in studies using the products, especially in the initial years, but many studies were also conducted from downloaded data and without any 
exchanges with the MCRMP team. Therefore, no filtering on authors was applied.

A major bias when trying to perform an exhaustive review of the use of MCRMP products quickly appeared when analyzing each reference. Namely, many papers referred to MCRMP while they actually used the UNEP-WCMC product, resulting in commission errors. Furthermore, it seems clear that the differences between the products was not always properly perceived by the users (see Discussion).

Considering this bias, we decided to switch our review strategy and instead of trying to be exhaustive by listing all MCRMP-based performed studies, we aimed to identify and list at least one study to represent as many topics as possible (e.g. conservation, fishery, remote sensing, climate forcing, etc.). In other words, from these stu.ies that did not make any confusions between products, topical representativeness w is s jught for, and not overall exhaustivity. If several themes were treated in one paper, top cs were ordered hierarchically with the main theme put first. From each paper, we alcn 1 inted: the study objectives, country, region, area, and level of description of MCRMP pro '"'sis (its thematic resolution). We also flagged studies when MCRMP data may 'a'e been inappropriate for the intended application, considering their hypotheses, $\mathrm{sc}_{n}{ }^{\prime} \mathrm{es}$, and type of analyses. References used for this study are listed in Table 1.

Another bias, less critical but freque.'t, is when authors used MCRMP data but do not cite any source, resulting in omission e re. This happens frequently, notably at the most basic level of use, for instance when th $\mathrm{e}$ a 'thors provide a location map to describe their sampling sites. In this case, it is obviou. ${ }^{1} \mathrm{y}$ difficult to search and identify such studies, but we came across many examples, minstly randomly, when consulting articles of interests in other contexts than the presen rev $2 w$.

\section{Results and Discussion}

A total of 62 studies were eventually selected and scrutinized for this report. These studies could be categorized as follows:

- 1) Coral reef visualization and inventories,

- 2) Conservation planning,

- 3) Enhancing the monitoring, spatial representation and description of coral reef biodiversity and ecological processes,

- 4) Fishery resource assessment,

- 5) Incidental benefits for the description and mapping of other ecosystems and the study of non-coral reef species,

- 6) Evolution and coral reef connectivity modelling, 
- 7) Coral reef and climate change modelling,

- 8) Geological processes

- 9) Carbonate budget

- 10) Socio-economic applications

Four topics were more represented than others, namely 'visualization and inventories, 'conservation planning', 'fishery resources' and 'connectivity modelling'. Because several papers could be related to several of the topics above, we organize hereafter the discussion according to seven synthetic topics, namely, MCRMP for: 1) coral reef visualization and inventories, 2) conservation planning, 3) enhancing the spatial description of coral reef biodiversity and ecological processes, 4) fishery resource asses nent, 5) Incidental benefits for the description of other ecosystems and the study of non cor: 1 reef species, 6) Evolution and connectivity modelling, 7) Modelling of future reefs i ' a c imate change era, and a last 8) all other studies.

\section{MCRMP for coral reef visualization and inventories}

The initial intended application of MCRMP was to provide accurate statistics of coral reef areas at national scales in a consistent fashior, $1 . \sim$ der to allow trans-boundary analysis and comparisons, and coherent planning. All GI, solcware can be used to extract statistics at any level of description (L2 to L5) as a user may vish for his needs.

The value of MCRMP quickly emer ${ }^{-2}$, hen comparing with previously available statistics that may have suffered from in ${ }^{\prime} n_{\text {: }}$; ent description (e.g. sometimes including lagoons, sedimentary areas, or just shal ow hard bottom areas, see Spalding et al. (2001)). Range of discrepancies reached easily a factor 2, but sometimes much more (Andréfouët et al. 2006, Wabnitz et al. 2010). Er.Or in MCRMP have also been reported. For instance Cohen et al. (2013) reported 2 missing coastal reefs for the Solomon Island product, although it is not clear which were the mısing reefs and the reasons (cloud cover, small size, etc).

Several countries and archipelagoes have been the object, on request or with additional funding, of e-Atlas (electronic atlases, often not available on papers to limit costs), provided as pdf files, with detailed pre-computed statistics per island at the Level 5 of classification, for instance for Papua New Guinea, the French overseas territories, for the Central and Western Indian Ocean (Andréfouët et al. 2008a, Andréfouët et al. 2008b, 2009), and for all Pacific countries but Fiji which was not available before 2008. Book chapters, monographies, and papers have also provided detailed statistics, for instance for New Caledonia (Andréfouët et al; 2009), UK reefs (Hamylton and Andréfouët 2013), or Cuba (Andréfouët and Bionaz, submitted). Such atlases and publications will likely be continued on an opportunistic basis. 
The most basic utilization of MCRMP products is the display of coral reef locations in a realistic way, for instance to overlay the location of coral reefs over sampling stations or some statistics. While the products are often referenced, in many instances, it is not the case. See for instance Riegl et al. (2012) for Chagos, Miller et al. (2018) for the Lau Group in Fiji, Boussarie et al. (2018) for New Caledonia, or the Pacific Ocean report of the Global Coral Reef Monitoring Network (Moritz et al. 2018). However, even when MCRMP is not cited, it is possible to identify the source by recognizing specific polygons and the overall level of details.

The simple visualization of coral reefs in a realistic way also motivated most of Pacific Island countries to request the products for their environmental or is shery management offices. While it is difficult, in an academic review context, to trac th ough publications how the products have been used in a governmental office, we $n$ te $t \mathrm{t}$ at the products are present on national geographic data web portal when they exist, ana ontribute to national statistics. For instance, see the New Caledonia portal http://geor....1c or the French Polynesia portal https://www.tefenua.gov.pf/. The compilation o s satial layers for Tonga (Smalhorn-West et al. 2020) expresses in a scientific paper the rrinciples of these multi data sets portals that generally compile both land and marine ${ }^{\top}{ } t_{\curlywedge}$ sets for all stakeholders (government, scientists, private sectors and general public).

Several papers have also now con prad MCRMP products with higher spatial resolution products in various places. Thi $1 \mathrm{~h}$-ludes for instance the north atolls of New Caledonia (Lyons et al. 2020), and Ad. irantes in Seychelles (Hamylton et al. 2012), plus several comparisons when mappin at $_{\mathrm{r}} \mathrm{g} \mathrm{gh}$ spatial and thematic resolution various areas (in Mayotte, Papua New Guinea, Fre ich 'olynesia, etc.; see Figure 2 afterwards). The general trends are agreement, but precise c mparisons can be meaningful only at geomorphological level and are dependent of the classification scheme and the sites. These papers, and others (Dalleau et al. 2010), clearly shows that many maps can exist for a given site, all providing different information potentially useful in different contexts. However, and more importantly, we find inadequate use of MCRMP when comparing inventories through time when using different type of maps. For instance, McClenachan et al. (2017) used MCRMP maps with other map products for the Florida Keys to estimate the loss of coral reef areas. Unfortunately, in this context, the MCRMP product is not adequate. MCRMP is not conceived to conduct any change detection analysis and no such work should be performed (Andréfouët et al. 2006).

Coral reef extent has most of the time been estimated globally using some of type of charts (Smith 1978, Spalding et al. 2001, Vecsei 2004), models (Kleypas 1997) and then recently 
remote sensing (Andréfouët et al. 2006) or a combination of multiple sources (UNEP-WCMC product). Recently, (Li et al. 2020) used several MCRMP Level 4 products (version available before 2008) to train a classifier to identify reefs on a global true color Planet Dove mosaic. The Level 4 classes were reinterpreted by $\mathrm{Li}$ et al. (2000) into multiple reef classes considering the different resolution provided respectively by Planet Dive imagery $(\sim 4.5 \mathrm{~m})$ and the MCRMP discernible unit of about 1 ha. Although they conclude that their model performances were affected by inaccuracies in the extent or category of reef in the MCRMP training data, strangely, the accuracy of the product, or the tuning of the probability thresholds, were quantitatively tested against lower quality products than MCRMP, namely Spalding et al. (2001) (which often have a factor 2, in exces or in deficit compared to MCRMP surface areas) and UNEP-WCMC (which incluc e $n$ n-validated MCRMP preproducts). Some of their choices (considering passes or (eep 'agoon as 'water') can also be argued. They also considered several types of MCRMD la soons as reefs, but many MCRMP lagoons are also missing from their projections. Hence Li et al. (2020) new map of coral reef, based on probability compared to other ro incts brings in itself many questions and inaccuracies, and cannot be considered a bett $*$ product than actual map derived from remote sensing observations. Same conclusions ${ }^{\prime}$ ld be done for the previous models of coral reef distribution, which were too coarse to he able to resolve many fine features (Kleypas 1997).

\section{MCRMP for conservation plannin!}

MCRMP products are often used in $\mathfrak{s}_{y}$ 'tematic Conservation Planning (SCP) (Margules and Pressey 2000; Kukkala and M silia'en 2013) to inform the design of marine protected areas (MPAs). SCP require biologica' nabitat and socio-economic spatial data, as well as specific optimization schemes that . re implemented in toolboxes such as the MARXAN software. SCP often define consu vation objectives using biological (e.g. species) and physical (e.g. habitat types) features tuat need to be met while minimizing some socio-economic costs. In order to foster the protection of marine ecosystems, international conventions and agreements have emerged, with requirements for the signatory countries to increase the size of their protected coastal and marine areas. For instance the Coral Triangle Initiative recommended that at least $20 \%$ of each coral reef-associated habitat should be included in no-take areas (CTI-CFF 2013, White et al. 2014). As such, MCRMP was frequently used to set coral reef habitats conservation objectives and to calculate the percentage area of different habitats that is under protection.

SCP studies that have considered MCRMP products were purely academic or driven by governmental and NGO initiatives, based on the list of authors affiliations. Among the 
applications related to SCP, we can distinguish i) conservation gap analyses, ii) sensitivity analyses of conservation solutions to habitat maps and definition, and iii) SCP scenarios to investigate solutions based on habitat representation objectives and various environmental and socio-economic data sets.

Conservation gap analyses aim to identify areas where there is insufficient protection efforts considering the co-occurrence of a high level of remarkable features and threats. MCRMP data have been used to identify these remarkable features and gaps. Mora et al. (2006) pioneered this application globally using coral reef maps. Nationally or locally, numerous examples followed. For instance, in Fiji, Weeks and Jupiter (2013) used MCRMP to identify reef classes for which data were lacking and where collection v as needed. Andréfouët and Hamel (2014) also used MCRMP and a metadata invent ry 10 guide a gap analysis in Solomon Islands. They showed in particular that several rea: of very high habitat richness, and thus with potentially high conservation value, wers qa $^{+}{ }^{+}$-deficient compared to other, less habitat-rich, areas. These habitat-rich areas could ho prioritized in the future for data collection.

Globally, the Convention for Biological Dive ity (CBD, 2010) stated as part of the so-called CBD Aichi Biodiversity Target 11 that at least $10 \%$ of marine and coastal areas globally should be protected by 2020 using r $^{-o t e c t e d ~ a r e a ~ s y s t e m s ~ a n d ~ o t h e r ~ c o n s e r v a t i o n ~ p o l i c i e s . ~}$ CBD emphasized coral reef ecosyst $m_{\triangle}$ as part of Target 11 . A clear definition of 'coral reef habitat' is, however, still lackny when assessing these targets. Recently, Gairin and Andréfouët (2020) highlighteá vith New Caledonia MCRMP data the importance of having a clear definition of coral inef rabitats to assess ABT11, by showing how the scores of protection are greatly aff $=$ cte 1 depending on which level of habitat description is used.

Hierarchical coral reet map products like MCRMP represent a real advantage in conservation. Several studies checked the effect of different factors on conservation plans, including the habitat map thematic resolution (i.e., practically, the level of mapping in MCRMP data). Cheok et al. (2016) for instance studied in Fiji this influence with also two other key factors (planning-unit size, and socio-economic cost). They observed that thematic resolution impacted prioritization the least; the only directly observed effect was that the reserve surface area increased with the thematic resolution. However, prioritization was strongly sensitive to increases in resolution (except at level 4) when socioeconomic costs were spatially variable. Another example is for Wallis, Futuna and Alofi. Hamel et al. (2013) showed for these islands that conservation objectives (set at $20 \%$ of the area of each habitat) could not be achieved for numerous habitat types without including traditional fishing areas, 
hence without loss of fishing grounds for fishers. The level of this opportunity cost was however dependent on the thematic resolution.

Finally, besides the examples above, MCRMP data have been used in many SCP studies in the search of conservation solutions, as one of the many habitats, environmental and socioeconomic data sets. We can cite here for instance studies in Papua New Guinea, Solomon, Maldives, Madagascar, New Caledonia or Fiji (Green et al. 2008; Lipsett-Moore et al. 2010, Hamel and Andréfouët 2012, Allnutt et al. 2012, Deas et al. 2013, Tulloch et al. 2016, Cheok et al. 2018).

\section{MCRMP to enhance the spatial description of coral reef biodiversity and ecological processes}

MCRMP products can be useful to identify high priority conserraiion areas by the number of habitats present, but also when combined with biological $\gamma_{a} \ldots$ or environmental data. For instance, Hamel and Andréfouët (2012) and Lipsett- Mc $\sim \mathbf{r}$, et al. (2010) used MCRMP products with fish data in the Maldives and the So on on Islands to identify areas of high biodiversity, and thus protected areas candidates. In 'Jev. Caledonia, Andréfouët and Wantiez (2010) showed that different benthic structures a fish assemblages were linked to various reef geomorphological classes, justifying $\mathbf{u} \cdot \mathbf{u} \cdot$ of MCRMP data to stratify the monitoring of the Lagoons of New Caledonia UNES- 0 World Heritage Area. Green et al. (2008) also analyzed the distribution of biodivers 'v features with MCRMP products in Kimbe Bay, Papua New Guinea. By combining wi il MCRMP coral reef fish, seagrass, and estuarine communities data, along with $c$ her biological and environmental data, they were able to identify areas to achieve a patc tion of $20 \%$ for each of the above features. Ferretti et al. (2018) used MCRMP to est n $^{\prime}$.ie populations of two species of sharks by multiplying coral reef area by reef shan dt $\sim$ ci y data. They did not consider the different classes or their levels of description, but it is $n s$ sible that using a higher level of geomorphological description and specific classes could have provided more precise estimates for each species, if shark data, possibly from different places, could point to specific habitat uses.

Finally, Millennium products were also used to study specific coral habitats. For instance in Belize, Chollett and Mumby (2012) used wave exposure, locations of landmasses, and reef crests provided by MCRMP to identify areas susceptible to be dominated by Orbicella coral. In the East Caribbean, Williams et al. (2017) also localized Orbicella-dominated reefs using the level 5 'forereef' class to study the relationships between Orbicella reefs state and benthic and herbivorous communities. In Maldives, for Baa atoll, a UNESCO Man and the Biosphere reserve, Andréfouët et al. (2012) generalized extensive field data with MCRMP habitats to 
infer the spatial distribution of coral cover and dominant growth forms, before injecting this data set in conservation plans (Hamel and Andréfouët 2012). Andréfouët and Guzman (2005) measured the link between benthic (coral and sponges) and habitat diversity using a MCRMP prototype product. Using MCRMP as a surrogate of benthic or pelagic richness and diversity has received less attention than expected after this initial paper, but again, limitations and sampling bias on field data could be a reason (Van Wynsberge et al. 2012).

\section{MCRMP for fishery resource assessment}

In a coral reef fishery context, when coupled with species abundance data (for fishes or invertebrates), coral reef habitat maps can be used to better constraint sampling designs and scale-up biomass at the scale of islands or archipelagos, before 'ssessing the sustainability of exploited populations (Hamel and Andréfouët 2010). The Imp 'icit assumption is that the mapped habitat(s) represent well the habitat(s) of the targ ete' species. The outcomes can be used to design MPA networks that have fishery-orienteci jbjectives and constraints. However, resource assessment is also the domain where we for $\mathrm{id} \mathrm{n}$ ost examples of data misuses.

At Pacific Ocean scale; Bell et al. (2009) broadlv scaled-up fish biomass using MCRMP reef and lagoon areas for Pacific Ocean countrie, $\cdots$ ank them based on forecasts of the fish required in 2030 to meet recommended per capita fish consumption, or to maintain current consumption as estimated from householu surveys. The model allowed to point out to countries where coral reef fishery wilc not meet food security objectives, which were 16 out of 22 countries. No scaling $w^{\wedge} p^{\sim}$ iormed for a specific (group of) species, and the fish biomass and yearly yield of 3 tor ^es per $\mathrm{km}^{2}$ of reef was generic, based on Newton et al. (2007). There was much roon ${ }^{\text {to }}$ enhance this scaling regionally and locally through better modelling, with locally esi nated fish biomass and revised yields (McClanahan and Azali 2020), fishery and hu: senold socio-economic surveys, distances to markets, and local management practices. An example of such refined analysis, still based on MCRMP data, can be found in Dacks et al. (2018) for a series of villages in Fiji.

Sampling strategy in a coral reef fishery context were helped by MCRMP products in several instances. For instance, the ProcFish project sampled 17 countries in the Pacific Ocean between 2002 and 2009 (Pinca et al. 2009, 2012). Four sites were selected and investigated for each country, and for most of the sites the commercial finfish (91 commercial genera and 392 species) reef sampling stations were selected using MCRMP data (e.g. for Kiribati, see Awira et al. 2008). Surface areas of different reef types were also used for the analyses of multiple fish guilds (Pinca et al. 2012). Several interesting examples of species-level modelling can also be pointed out. For instance, still in the Solomon Islands, Pearse et al. 
(2018) evaluated vulnerability to fishing pressure of two large, iconic, but declining coral reef fish species, the 'Napoleon' humphead wrasse (Cheilinus undulatus) and the bumphead parrotfish (B. muricatum). Responses to fishing pressure differed between the two species. Using MCRMP to define coral reef habitat types but also design their sampling strategy, Pearse et al. (2018) were able to determine the present habitat preference of these two species, their abundances and distributions.

Other interesting studies focused on existing management approaches for fishery resources, like locally managed marine areas (LMMA) (Govan et al. 2009). LMMA are generally small coastal areas managed by local villagers and communities. These often use purely local rules, cultural habits, and customs. Cohen et al. (2013) and Jupite st al. (2017), for example, focused on periodically harvested closures (PHC) in LMMAs By using land-based records of fish catches and MCRMP to calculate fishing ground ar sas, Cohen et al. (2013) estimated daily fishing efforts of PHCs after their opening, whis was compared with reef areas adjacent to PHC zones and open for harvesting alı ar-round. Their results suggest that when PHCs open up, there is an increase of ove al fish catches. Jupiter et al. (2017) assessed management tool efficiency by estimating $\mathrm{p}$ : ttection of resource units (using targeted fish species biomass) and biodiversity c. $\eta_{\text {s }}$ rvation (using fish diversity). The level 3 geomorphological classes were used in characterize the environment of the LMMAs. Unlike Cohen et al. (2013), these authors or.t that PHCs presented few benefits for biodiversity conservation with only one (out or Q PHCs studied) containing a higher reef fish diversity, which could be explained $i$; the specific reef slope geomorphology rather than by conservation effects.

Several problems also e ner $ə$ d when using MCRMP data in a fishery context. Problems are generally related to a lac's of precaution (or data) when pairing (or not) geomorphological classes and species. Using the ProcFish underwater visual census (UVC) data combined with several other datasets, Harborne et al. (2018) established in Micronesia (Marshall Island, Palau, Federate States of Micronesia, Guam and Commonwealth of the Northern Marianas) a model to estimate fish biomass and fishery impacts to inform and help coral reef management decisions. A total of 19 fish species where included. They merged these species data with Level 4 MCRMP classes to delineate habitat types and to estimate fishing grounds. Although the exercise can be done, its value for management and accurate stock estimate is entirely dependent on the fish sampling scheme and the biomass scaling to habitats level, which in this case missed several important and extensive classes (such as lagoons), hence omitting potentially important habitats. Conversely, habitat commission errors can be shown. For 
instance, still in Micronesia, Weeks et al. (2016) reviewed MPAs of Pohnpei Island and proposed a new MPAs network using MCRMP products. Based on recommendations by Green et al. (2008), they decided that MPA size should be twice the home range of the species requiring protection. However, all 'shallow geomorphic reef classes' were considered as potential habitats for the focal species. In this case, further research, and local data collection, should be necessary before making this assumption. In the Solomon Islands, Hamilton et al. (2017) used MCRMP products to assess the influence of reef habitat types on adult abundance of bumphead parrotfish (Bolbometopon muricatum) and to identify the reef habitats of juveniles, which were solely found on sheltered lagoonal fringing reefs. Where juveniles' habitats were identified, they estimated the local logg ${ }_{1}$ ? impacts on the habitats by measuring water clarity. However, what was done for the sur ey ampling strategy is unclear and it is difficult to judge if MCRMP classes (one or seve al) v ere correctly used to represent juveniles' habitats. Sometimes, only one MCRMP clacs - nuld be linked to a species habitat with confidence, prior to infer stocks and manageme. ${ }^{*}{ }_{-}$commendations (e.g., for the green snail, Andréfouët et al. 2014). This may probr ol occur frequently, and extensive surveys were needed to establish even such a simple r' 'ationship (Andréfouët et al. 2014).

Incidental benefits of MCRMP produc * or the description of other ecosystems and the study of non-coral reef species

A noteworthy application is the use 0 M Mllennium geomorphological classes to enhance the mapping of other, non-coral, ha sta ${ }^{+}$s and ecosystems. For instance, Wabnitz et al. (2008) used the MCRMP classes to $p_{\mathbf{L}}$. rrit1ze location of specific seagrass mapping in the Caribbean. In the Pacific Ocean, coral reet ınaps were also used to better identify seamounts, which are important reservoirs o re ources and biodiversity. Seamounts locations still remain imperfectly known becat se their presence is estimated using satellite altimetry. However, numerous 'false positive' (i.e., detected seamounts which are actually sub-surface features) occur with this method. In Allain et al. (2008), Pacific Ocean databases on seamounts and bathymetry data were cross-checked with MCRMP products to identify false seamounts that were in fact shallow coral reefs, mostly low-lying atolls. The process eventually enhanced global seamount databases.

Investigating the interaction and relationship between physical features and between different ecosystems is also a developing research question in oceanic fishery since the results can explain oceanic resource distribution and other metrics. Allain et al. (2012) studied in the Pacific Ocean the relationship between oceanic and coastal ecosystems by analyzing stomach contents of tuna and their distance to reefs using MCRMP, and distance to land using the 
National Geospatial Intelligence World Vector Shoreline. From their model, they found that consumption of reef preys was more affected by proximity to land than proximity to reefs. Letessier et al. (2016), in Chagos, highlighted the ecological interaction between the mesopelagic realm (defined by a depth between 200 to $1000 \mathrm{~m}$ ) and nearby atolls with acoustic fish data, MCRMP, and seamounts location data, to estimate the distance between each sampling unit and its closest topography structure. In doing so, they showed that Chagos represented mid-water biomass hotspots in tropical Indian Ocean.

Coral reef maps were also helpful to model marine mammal distribution and movements around islands. For instance, in New Caledonia, Derville et al. (2018a, 2018b) studied humpback whale (Megaptera novaeangliae) social groups dis ribution and behaviors. In these two studies, using MCRMP, whale biopsies and GPS c ata rom scientific field surveys and from crowd-sourced data, they calculated the distanc $\cdot$ be ween humpback whale groups and the closest reef or land, and relate social behavinrs with the environment of different breeding grounds.

In the oceanic applications above, we note t'ra no use was made of specific levels of mapping and only the information on reef (att: bute REEF=1) was considered.

\section{MCRMP to model connectivity}

Understanding genetic and demogranhic con nectivity between marine organism populations through the distribution of habitat p:- he is the object of numerous empirical and modeling studies. Marine organisms can $\mathrm{m}^{:} \mathrm{raa}^{\circ} \mathrm{o}$ across a certain distance at various life-stages (e.g. through larval dispersal, and is a Jults through their home range size) and depending on spatial and temporal scales, thise studies can be oriented to processes related to population dynamics, evolution and spiciation, and conservation (Cowen et al. 2006, Carr et al. 2017). Understanding connect 1 ity help define the range of reef extent needed for conservation, their locations as well as the ranges of distances between individual conservation zones in order to maintain exchanges between populations (Sale et al. 2005). Related to this topic, seascape genetics aims to link connectivity with environmental factors affecting dispersal (Selkoe et al. 2009).

Environmental features (e.g. coral reef configuration, distance between habitat patches, current velocity, larval dispersal duration, etc.) can act as a barrier to genetic and demographic flows resulting in variations at regional scale. For instance, the concept of isolation by distance (IBD) is often used to link genetic structure with distance between habitat patches (Wright 1946). Van Wynsberge et al. (2017) using an IBD model tried to explain the genetic structure of giant clams in the Western Pacific Ocean and Coral Sea, 
between Vanuatu and New Caledonia. They used MCRMP products from Level 3 to Level 1. By comparing their results with genetic data, they showed that habitat configuration can enhance population connectivity modelling and comprehension. Kool et al. (2010) also used MCRMP Level 4 products, combined with other map products, to identify different coral habitat patches (e.g. patch reef, forereef, terraces and others) in the Caribbean Sea. They combined the resulting maps with current velocity data and created a dispersal model to explain the genetic break observed between the Eastern and Western Caribbean for coral species. Their model showed the formation of regional clusters with individuals who tend to settle near the source population. The Kool et al. (2010) model was later tested by Foster et al. (2012) with genetic data, and a multi-coral species extersion was implemented by Holstein et al. (2014) this time using MCRMP and WRI data.

At post-settlement stage, for juvenile and adult movem nts, Weeks (2017) used MCRMP maps and a mangrove layer to calculate distance betrrec: nursery and adult habitats of the bumphead parrotfish (B. muricatum) in Yap Islan. Micronesia. From this, a seascape connectivity metric and cost function was deriv a $n$ identify conservation areas to prioritize. This study is an example of the growing nur her of applications that consider SCP scenario for fishery targets and with connectivity $\sim \mathrm{c}$ straints, and is an example of multi-topics study (Table 1).

Theoretical studies have focused in renness and self-persistence of populations under spatial constraints through habi at ristribution. Using MCRMP data to calculate realistic spacing between habitat patch . P1nsky et al. (2012) identified open and closed populations using larvae dispersal moc'ls and spacing between habitat patches in Bahamas and Papua New Guinea. Afterwar ts, hey created a generic model to link habitat patchiness and dispersal ability with pc sulation openness. Their results quantified how population selfpersistence depends on the relationship between patch size and dispersal while population openness depends on the spacing between habitat patches and dispersal.

\section{MCRMP and the modeling of future reefs in a climate change era}

As climate change is accelerating and its impacts are increasing, simulations and models are developed to forecast the effects of global warming on coral reefs with the intention to propose solutions to mitigate the impacts (IPCC 2014). Thus far, to predict the impact of climate change on coral reefs, models in their most simple form combine maps of thermal stress, at present time or under various IPCC climate scenarios (e.g., RCP 4.5 and RCP 8.5 for intermediate and pessimistic scenarios, respectively), overlaid with coral reef locations map to infer where the most exposed (to coral bleaching) and safest coral reefs would be 
(Van Hooidonk et al. 2013), and what the extent of coral reefs could be in future time (Freeman et al. 2013). In several cases, MCRMP is referenced, but it is actually the global UNEP-WCMC product, also referenced, which was primarily used (e.g., Van Hooidonk et al. 2013, 2014). Only a single reef layer without geomorphological details was used.

In more sophisticated models, the dynamics of local biological communities are exposed to climate change-related threats. Several scenarios have also integrated in the equation other stressors such as acidification (Van Hooidonk et al. 2014) but also data on socio-economy, fishery, land-use, pollution and hurricanes, for instance in Meso-America with the CORSET simulation tool, Melbourne-Thomas et al. 2011). In the Bahamas, Silver et al. (2019) used MCRMP data to assess with the InVEST Coastal Vulnerability in nel the spatial variations in coastal protection potential to sea level rise, storm surges, $\mathrm{t}$ ood ng and erosion. This study stands out in this review because it uses mangroves, coral eef and seagrass layers. However, even if the MCRMP was used to represent coral reef luations (e.g., for Meso-America in Melbourne-Thomas et al. 2011, or Bahamas in Silver - + al. 2019) only the simplest reef layer was used, without geomorphological details $(\kappa \mathrm{rFF}=1)$. Furthermore, the combination of various sources of coral reef location data te complement MCRMP or the WRI product is common in numerous Caribbean-scale (. g, Holstein et al. 2014) or sub-region-scale papers (e;g., Chollet et al. 2017).

In Africa, MCRMP was used in $\mathrm{mu}^{\prime} \mathbf{1}_{-}$.. iteria contexts for climate change vulnerability study, using spatial planning tools as iu lie Conservation section presented above. These studies also took advantage of using si rera geomorphological classes. Maina et al. (2015) identified conservation areas in Ken, 7 ac ording to different fishing and habitat-based scenarios and ensuring that these are $s$ a e climate resilient by considering their exposure to climateinduced stresses. They u sed the Marxan prioritization tool based on a criteria of habitat representation which was MCRMP-compatible (i.e. mapped at high resolution but with MCRMP Level 3 geomorphological attributes). The solutions were most sensitive to whether the emphasis was put on protecting the least or the most climate exposed areas. In Madagascar, Allnutt et al. (2012) identified areas for conservation with Marxan and Zonation spatial prioritization tools using three parameters: thermal stress exposure, fishing pressure, and finally biodiversity in which 16 coral reef geomorphological classes were included.

Throughout the world, the estimation of the carbon and carbonate budget of a coral reef environment provides insights on the health and growth of the communities, the local sedimentology and accretion, and overall the role of the reef in the carbon cycle, which is a key information in a global change context to quantify carbon sinks and sources (Perry et al. 
2008, Lange et al. 2020). A budget serves also to estimate the capacity of a reef to maintain its ecological services, such as coastal protection. A metabolic budget compares carbonate production from corals, coralline algae, and a variety of calcifying organisms (mollusks) with mechanical, chemical and biological erosion. The census-based method recently applied on several coral reefs aggregates the performances of individual building or eroding components at a fine local scale (Lange et al. 2020). Due to the relative stability of metabolic performances for several typical communities, reef and archipelago-scale budgets have been estimated by using map of these communities and standard metabolic rates. In Florida, Moses et al. (2008) used this approach with MCRMP, other benthic mapping products, and local metabolic measurements to estimate the overall contribution or the Florida Keys in term of gross production, net production and calcification. Simple $m_{\mathrm{n}}$ dele ; also suggest sensitivity of these values to ocean acidification, with increased local di solt tion of carbonate sediments.

\section{MCRMP for other topical studies}

Less represented in the literature are several exar sles of MCRMP-based study that we report here. They cover applications in phvcical oceanography modeling, geological processes, and socio-economy.

The MRCMP layers were used to infe re listic shallow water bathymetry for previously uncharted areas and allows the enhancemen of hydrodynamic numerical model in coral reef environments. Lindo-Atichati et al $\left(2 v^{\prime} 5\right)$ used this process in Meso-America to better resolve currents and surface trans ${ }^{r}$ rtt . iound reefs. Similar process is currently implemented in New Caledonia (J. Lefevre, 1,ers. comm.).

Still in New Caledonia, Andre? ${ }^{-}$uet et al. (2009) used MCRMP, bathymetric multibeam data and coring data to revif $\mathrm{w}$. he complex suite of geological processes that have shaped the coral reef formations - t inis archipelago. In fact, while such synthesis work was not published for other regiuns, similar comparisons made at the time of the genesis and early years of the MCRMP project were instrumental to design the MCRMP typology. In particular geological and sedimentological map from the Great Barrier Reef in Australia, French Polynesia, Panama, Belize, Maldives and Indonesia were critical (see references in Andréfouët et al; 2006).

Finally, In Kiribati, where MCRMP was used to calculate reef areas associated to each individual island, Reddy et al. (2014) reported conflicts between conservation and activities. Their results highlighted an increase of fishing labor, and of its impacts on reefs, in response to rising copra price. This example shows how coral reef surface areas can be used in economic models, beyond just purely fishery aspects as discussed above. Economic valuation 
of coral reef services, at reef, island and archipelagic scales have received lots of attention in the past 20 years, (e.g., Albert et al. 2015 for the Solomon Islands, Pascal et al. 2015 for Vanuatu). However, while scaling fishery yield, as a biomass, has been done in many cases as described in the Fishery section above (e.g., Bell et al. 2009), we surprisingly did not identify studies in the literature that could have benefited from MCRMP to scale-up local (village scale) areal-based estimates of services for their monetary economic value.

\section{Synthesis following a SWOT framework and lessons for future project}

The review performed here could not exhaustively list all the studies that have used MCRMP data, since they are often uncited. Nevertheless, from the review performed here, it is possible to highlight a range of applications, and the strengths, weaknt .es, opportunities and threats (SWOT) of the MCRMP project and its products (Table 2). We helieve it is also possible to suggest useful recommendation if similar high resolv.10. remote sensing projects are launched in the future, for tropical or temperate sysu ms that would investigate globally seagrass, mangroves, microbial mats, sedimentar: ar as or any shallow habitats and ecosystems of interest. We also believe it could apply to terrestrial, freshwater, and even urban mapping projects.

The major strength of the product was it hif arcuical structure and a design that considered a global consistent coverage. Even if it has not been fully completed globally, the design (before any mapping) and classific-tion scheme was global. This allowed a vast set of scientific studies, on various tor: ${ }^{-} \sim \mathrm{d}$ at a variety of spatial and jurisdiction (regional, national, international) scales. Maı: types of applications that have eventually emerged were unseen at the time of the pros $t$ creation. The creativity and needs of scientists took good advantage of the produ is. One of the first lessons is that a complex, thematically rich, hierarchical product is $\mathrm{n}^{\mathrm{y}} \mathrm{y}$. Although the number of references that have used the L5 level is low, the product offere flexibility and the Level 3 and 4 were popular (Table 1). However the number of studies that considered only a 'reef' information, without details also show that a simple product is critical. Therefore, we recommend that a simple product is provided first with high priority, before a more complex one is created. A staged strategy could have avoided gaps in the present global MCRMP coverage, the need to merge different products, and the frequent confusion with the UNEP-WCMC product, whom popularity also shows the interest in using a simple product. However, it should be emphasized that a binary REEF-NO REEF product is a gross oversimplification of the reality. It inherently suggests that except in their latitude, longitude, all reefs are similar (in structures, benthic composition, health, and so forth. Only the environment (e.g., distance to land, climate, etc.) of the reefs, and their 
history of disturbances if it is taken into account, can be explicitly different, but not the reef itself. This is obviously a very significant simplification, similar to considering that all tropical forests would be equivalent on terrestrial ecosystems.

The use of a binary UNEP-WCMC product was probably seen by many users as a compromise to achieve a global coverage for a given study. One may think that if a global MCRMP thematically rich product was globally available, it would be used. However, it is not so clear. The possibility to be more specific, and to use one or several of the geomorphological levels for a particular topic, is inherently limited by available knowledge, and by previous field sampling effort. Even for the relatively average complexity product shown Figure 1 for Huahine Island, very few field programs cáı afford to collect data for 17 Level 5 geomorphological units. Therefore, it seems tha the use of the full thematic resolution was condemned to be limited, from the start. i $\mathrm{y}$ ir sufficient ancillary knowledge and data that can be matchd with all MCRMP classe wie use of all the MCRMP thematic richness is possible when it is used standalone, with ' $\cdots$ direct connection or merging with ancillary data. These standalone applications $\mathrm{e} \times \mathrm{p}$ ain the a priori choice of aiming for the highest possible thematic richness at the ti ne of the project genesis. This allowed, for instance, the setting of habitat represen ${ }_{\iota}$ tir $n$ conservation objectives in systematic planning scenarios, which was a popular applic tion.

Although is it not apparent immedi it $f_{1}{ }^{\prime}$ trom the reviewed papers, there was little criticism on the accuracy of the products ( Ju s ee Cohen et al. 2013, and Li et al. 2020 that we discuss above). Several reasons can $\mathrm{e}_{\boldsymbol{\Lambda}_{1}}$ lain this. The first one is that users most likely do not really question a from-the-shelf p-ndu -t. In the past years, the number of users who directly asked clarifications on the inte pret ttion of sometimes very complex products (like Fiji, Papua New Guinea or New Caledonı $\imath$ ) was surprisingly low. In fact, they were less than five in total. They were all questions from scientists and students, while the products have been directly distributed to tens of users from various backgrounds (scientists, NGOs, government offices, private sector) and probably reached directly or indirectly hundreds more. The second reason is that the level of mapping (geomorphological) considered for the project was selected specifically to limit errors, and without having to rely on costly ground-truthing data. True errors compared to the reality on the ground are related to clouds or turbid waters obstruction preventing the mapping and to the Landsat sensor specifications. The spatial resolution, georeferencing errors (which can reach 300 meters) and the inherent limitations in term of minimum discernible unit (MMU) which is around 1 hectare $(100 \times 100 \mathrm{~m})$ also characterize the products. Specific to the MCRMP product, the interpretation of geomorphological 
structures for a given site can be multiple, and some choices made by the mappers may not be intuitive for a user. However, these are not true qualitative or quantitative errors. The strength of MCRMP, which can be a lesson for other projects, is therefore to have avoided levels of description that are easily prone to serious misclassification errors and, for cost-effectiveness, to not have relied on any ground-truth data, while still maintaining a high number of classes. Another example can be given: accurate seagrass mapping at Landsat spatial resolution without ground-truthing is impossible beyond mapping areas of dense to medium-dense seagrass beds (Wabnitz et al; 2008). No information on species presence/absence, biomass, or canopy height can be inferred. Yet, a simple consistent product at a simple level is useful at

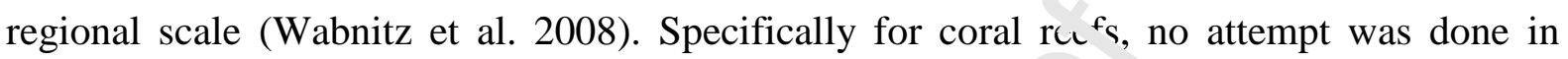
MCRMP to map any benthic features at community scales ( a.g. coral cover). Furthermore, the selected levels of description (geomorphological) 'lso Narrant that the product will remain valid even for the next generation of scientists anci managers. Indeed, geomorphology is impacted at very long temporal scales, unlike wistic features that may change very quickly from one year to the next, due to ile fast dual action of natural growth and disturbances.

The vast majority of applications used Mr_RMP to obtain a realistic, accurate measure of distance or surface areas for some ke, reef classes, or for the whole REEF=1 layer. Providing better areal metrics and maps was ir $d f^{-1}$ the first purpose of the project. These metrics make extrapolations and models on a $v$ url $^{\mathrm{v}} \mathrm{v}$ of thematic much more reliable (e;g., in a connectivity context, see Pinsky et al. 20:7). However, it is also clear that despite its rich typology, MCRMP could not fill all the ıeeds. This cannot be shown from the review, as we cannot review studies that have not been made, but a parallel is possible with other remote sensing studies that have used c ifferent products at higher resolutions, for instance in a fishery context (Hamel and Andréfouët 2010). The weaknesses of MCRMP in fact often, but not always, mirror its strengths, due for instance to the Landsat sensor specifications, as said above. The avenues for improvement clearly include the development of geomorphology products but at a better spatial discrimination limit of 1 hectare achieved from 30 meter resolution satellite image, hence on what would be a Level 6 (using 5-10 meter resolution data) or even further a Level 7 (using 1-5 meter data), and still without ground-truth data (Figure 2, Supplementary Material Tables S1 and S2). For instance, the spatial resolution of Landsat prevents, with a related MMU of 1 ha, the mapping of very patchy areas (Figure 2). The rendering of structurally complex areas, like spur and grooves, small patch reefs, reticulated reefs or narrow crests may be needed for various applications. A 
geomorphological Level 6 and Level 7 will authorize this, while still maintaining the hierarchical structure of the classification scheme, and not entering the difficult (and impossible) mapping of benthic features consistently, accurately and globally. However, it must be clear that a jump of one to two levels should mean also one or two orders of magnitude in coral reef geomorphology expertise, human workforce, processing time, and costs (Figure 2).

A possible weakness, but inherent to the initial objectives of the project and the mapping choices, is that MCRMP products are unsuitable for change detection studies that would use directly diachronic series of the sproducts. This would be no sense with the current MCRMP spatial and thematical resolutions. However, the product themai - richness allows to stratify where change detection, based on higher resolution images or fiel 1 work could focus on, such as reef flats (Scopélitis et al. 2009, Scopélitis et al. 2011, An lréfouët et al. 2013, Ampou et al. 2018). To be able to perform change detection from $t_{1} \times$ products themselves, it would be necessary to increase the spatial and thematic resoluth $n$. Higher thematic resolution is often linked to an increase in spatial resolution and 'te size of the mapped objects of interest become smaller and more susceptible to $c$ ange. This increased spatial and thematical resolution, which would be provided at ar levels 6 or 7, would translate as objects of few tens of meter squares and few meters : quare respectively. Moving towards a Level 6 or Level 7 geomorphological product could c pe . some change detection application, like movement of shorelines (Duvat et al. 2017) o ca-honate mega-boulders as they are found on some atoll reef flats (Bourrouilh-LeJan . nd Talandier 1985).. However, most of the interests, and challenges, in coral reef hange detection occur at benthic level, to study short term to decadal disturbances anı rec very processes (Scopélitis et al. 2009, Ampou et al. 2018) that can be driven by a pletho a of processes. Changes that would be visible directly on MCRMP products can happen only at geologic time scales or after very high energy events, such as the 2004 Sumatra earthquake after which submerged coral reef flat of the Mentawai archipelago have been uplifted and became part of land (Metltzner et al. 2006).

In term of opportunities, the products can still benefit many projects and also benefit from others. For instance, a number of regional scale atlases and products have now been made at higher thematic and spatial resolution using 2-4 meter satellite images, but for regional areas (Bruckner et al. 2012 for part of the Saudi Arabia Red Sea coast). Other initiatives are also moving forward to try to compile a global product and process country by country (Allen Coral Atlas, Lyons et al. 2020). It would be valuable to set the context of more detailed work within the context described by MCRMP, for instance to be aware of the percentage (in 
surface area, number of classes, etc.) that the detailed product represents compared to the areas covered by MCRMP. If specific, locally optimized, geomorphological typologies are developed (e.g., Rowlands et al. 2014), it is possible to make the correspondence, and also potentially mutually enrich the local typology and MCRMP's.

Several opportunities of new applications can also emerge. For instance, many places are more studied, critical, and in need of management and spatial plans than others, hence MCRMP statistics can be used to prioritize or not, more detailed mapping for the most critical areas, while less critical areas could be left at a level similar to MCRMP. This triage strategy could be based on approaches similar to Andréfouët and Hamel (2014), by looking at density of references and places that have used mapping produc Other possibilities include the development of multi-ecosystem products, for instance cc nbi ing coral reef, seagrass and mangroves that are still missing in many places, especially Sol th-East Asia (Torres-Pulliza et al. 2012). Several of the recommendations above shoיil 've followed for this ecosystem trio too, namely: staged mapping with a simple product 1. and thematically rich products but still easy tr $\mathrm{r}$ a p accurately without ground-truthing to limit costs.

Before discussing the threats related to :Tr,RMP products, it is necessary to clarify if these are threats for map users or for $\mathrm{man}_{1}$ producers. We suggest both are related. Indeed, it appears to us that the confusion be $\mathrm{w}_{0}, \mathrm{n}$ products (as a first obvious problem) is a serious issue for both users and produce s. This confusion was obvious in many papers that refer to one product (MCRMP) while $\mathrm{s}$ ing others, generally of lower thematic and resolution quality but with higher spatial cov ragt (UNEP-WCMC or WRI). Examples of mis-citations can be found in Schill et al. (2C 15), Brown et al. (2017), Cinner et al. (2018), Garavelli et al. (2018) among others. Schill et c l. (2015) used current velocity data and WRI and to model coral connectivity in the Caribbean Sea, but they refer to MCRMP. This is also probably the case for Garavelli et al. (2018) who identified for a conservation-oriented project the selfpersistent populations of spiny lobsters in Caribbean using a population and larval dispersal data and other information about broad-scale connectivity. In a Fiji study to track the causes of poor water quality back to land use, Brown et al. (2017) mention the use of global coral reef map product, but cite a MCRMP reference (Andréfouët et al. 2006). The provided maps do not allow the identification of the product. Hence it is unclear which product has been used. All these studies, and many others, are rather unclear in terms of data sources. It seems that authors may confuse the sources and may actually also take a product for another. In some cases, the wording in the studies suggest that it is believed that UNEP-WCMC product 
is just a redistribution of the MCRMP product, without information loss.

Generally, what a product includes is quite clear, from the metadata (and references within) or from the web site portal that offer the products or from both. This informs the first user in a chain of distribution. However, second-hand distribution is uncontrollable regarding which information is transmitted. There are no commercial rights on these products and a licensing process, even free, if out of the question. To conclude here; it seems wise to try to avoid multiple data distribution schemes and especially confusion between products.

Another threat, but clearly for the users this time, is an improper use of MCRMP products due to a scale mismatch between the application at stake, ancillary data and the MCRMP data. We found most misuses in the applications related to thı spatialization of ecological processes and fishery assessments. In particular, a weak or I nproven link between the mapped habitats and the species' habitats can be a source of $\mathrm{f}$ roblems. As mentioned above, this is largely due to lack of biological data, and usere s' ay make omission or commission errors in the species-habitat applications because o these data gaps. Part of the solution might be in providing better documentation, trall ing and product application guidelines to avoid misuses of products. But many anpl: ations were not planed beforehand, and for instance it was certainly not planned to tr cument the suitability of each geomorphological layer to represent the habitat of a mu'titude of species of interest (e.g., bumphead parrotfish for instance) which could easily rear $n$, veral hundreds of key species.

The Table 2 provides a summary of $h_{1}$ SWOT discussion.

\section{Conclusion and recommendia. ions}

The Millennium Coral Reef Minping Project aimed to map coral reef worldwide for science and management appl aai ons using consistently a unique hierarchical typology of geomorphological units considering that only 62 papers were reviewed here, we likely missed some rare or unpublished applications but it is apparent that MCRMP products were used prominently for coral reef inventories; conservation planning; enhancement of biodiversity and fishery resource mapping, monitoring and modeling; connectivity and climate change modeling; and various applications on oceanography modelling, geology and island socio-economy. The products were also useful to map other ecosystems. Users were academics, who are dominantly represented in a review of peer-reviewed literature, but also governmental and non-governmental organizations, and managers. The greater use of complex product (using Levels 3, 4 or 5) were achieved at archipelagic, regional and national scales. This scale is logical because it also often means that the targeted area often has political, environmental, socio-economic and cultural homogeneity. This relative 
homogeneity naturally bounds the domains of analyses, in which ancillary data coverage may also be more homogeneous than at global scale, and funding coverage as well. The quality of Landsat images allowed by design a complex mapping and this review suggests that the high complexity of the product, which was intended to maximize flexibility of reef description for a variety of application, met its objectives and was successful. The integration of the MCRMP products into other global or regional lower resolution products (spatially and/or thematically) allowed more applications to be performed with increased spatial coverage, but it also confused users. Mis-referencing suggest that many users may not be really aware of what products they are using.

Several lessons can be learnt from the MCRMP project. Tin -e can be useful for other projects that will look in greater details into coral reef map ing globally or regionally, and also for projects that will target uncharted coastal and shal ow :cosystems, but also terrestrial, freshwater and urban ecosystems (similar to the glohol it tal flats mapping in Murray et al. 2019). We highlight them through several bullet-poinı specifically:

- Even imperfect, we recommend to keep co di cting remote sensing based inventories for coastal and shallow water ecosystems, instead of relying on models for instance. Observations will be better than moi'l, although models can help filling gaps. Mapping can be seen as infrastructure anc development initiatives, and national research funding agencies should not neglect thi, $2 s_{1}{ }^{\circ} \mathrm{ct}$, even if a mapping project seems, wrongly, way too upstream 'real science a aplications. Many scientific and useful management applications will be booste. 'by availability of good products, as shown here.

- Second, it is necessary to r reate first a simple product with maximal spatial coverage, then elaborate $\cap n$ his o develop a hierarchy of classes and thematic refinements, possibly following a prioritization strategy based on scientific and management needs. The creation of a first simple but global product was probably what most critically missed the MCRMP project. Looking back, it is likely that too much efforts were spent on mapping in details areas from which no applications have emerged, or for which only a simple version of the product was used.

- Third, from this review, it appears that users do not question the products most of the time, and sometimes use them beyond their inherent limits. Hence, the product has to be accurate. It is not expectable by map producers that map users be critical of the product and make corrections on their own. Therefore, it is critical to avoid products with errors, and thus avoid description levels that easily generate errors. While a threshold may be 
difficult to establish, a $90 \%$ overall accuracy is probably the acceptable limit, especially if the products are used by managers and NGOs to implement real management decisions. Such a high threshold is also necessary when maps are combined with other data sets, especially biological, often with a higher level of uncertainty. Creating relevant applications is often a matter of linking with ancillary data sets, such as biodiversity inventories. Therefore, expecting very high accuracy from a map product is a matter of using a precautionary approach to further develop in confidence coupled spatial models and applications.

- Fourth, re-distribution, re-analyzing, updating, maintaining and merging products from various sources created confusion. While the confusion is rimarily explained here by users's lack of precaution, the map producers and data $d_{i}$ trit utors should also be careful and think about how to avoid these problems. A sig ific nt issue, not apparent directly from a literature review, but experienced by the au hors of this review, is that many institutions wants to have and distribute their own - oducts. This is to enhance their own visibility or to meet some commitments, io instance after submitting proposals and receiving funds. However, often, they we 'ld simply customize an existing product. This can be perfectly legitimate, and som tir.es value can be added, but it creates confusion.

To conclude, nearly 20 years aftc - the Oceanography Program of NASA committed to enhance the representation, descrir i( $\left.{ }_{1}\right\urcorner n^{\prime}$ inventories of coral reefs worldwide, it can be stated that the Millennium Coril isef Mapping Project was a cost-effective project that helped developing reef science and management. MCRMP data are part of the toolboxes of many researchers and mana ${ }_{i}^{*}$ ers and probably will continue to be in the future, in conjunction with other data sets. It al o b ing some lessons for future similar projects.

\section{Acknowledgements}

The Millennium Coral Reef Mapping Project was initially funded by NASA grants NAG510908 to SA and Frank Muller- Karger (University of South Florida), and grant CARBON0000-0257 to Julie Robinson (NASA). The project is now funded by Institut de Recherche pour le Développement for specific application and projects. We are indebted to the PIs, and to Christine Kranenburg, Damaris Torres-Pulliza, Alan Spraggins, Brock Murch and Chuanmin $\mathrm{Hu}$ for their time and hard work during the initial phase of project (2002-2007). The map of Mayotte in Figure 2 was done for the SIREME project (PI: Pascale Chabanet) funded by the X European Fund Development and the office of the Terres Australes et Antarctiques Françaises.

\section{References}


Albert, J.A., Olds, A.D., Albert, S., Cruz-Trinidad, A., Schwarz, A.-M., 2015. Reaping the reef: Provisioning services from coral reefs in Solomon Islands. Marine Policy 62, 244251.

Allain, V., Kerandel, J.-A., Andréfouët, S., Magron, F., Clark, M., Kirby, D.S., MullerKarger, F.E., 2008. Enhanced seamount location database for the western and central Pacific Ocean: Screening and cross-checking of 20 existing datasets. Deep Sea Research Part I: Oceanographic Research Papers 55, 1035-1047.

Allain, V., Fernandez, E., Hoyle, S.D., Caillot, S., Jurado-Molina, J., Andréfouët, S., Nicol, S.J., 2012. Interaction between Coastal and Oceanic Ecosystems of the Western and Central Pacific Ocean through Predator-Prey Relationship Stu' 'ies. PLoS ONE 7, e36701. Allnutt, T.F., McClanahan, T.R., Andréfouët, S., Baker, M., 'ag: brielle, E., McClennen, C., Rakotomanjaka, A.J.M., Tianarisoa, T.F., Watson, R., Kre nen, C., 2012. Comparison of Marine Spatial Planning Methods in Madagascar Lamonstrates Value of Alternative Approaches. PLoS ONE 7, e28969.

Ampou, E.E., Ouillon, S., Iovan, C., Andréfo'er, S., 2018. Change detection of Bunaken Island coral reefs using 15 years of verv 1. oh resolution satellite images: A kaleidoscope of habitat trajectories. Marine Pollutic F, ulletin 131, 83-95.

Andréfouët, S., 2008. Coral reef hab; tat mapping using remote sensing: A user vs producer perspective. Implications for re $e^{-\omega^{h}}$, management and capacity building. Journal of Spatial Science 53, 113-129.

Andréfouët, S., Riegl, B., 206. Remote sensing: a key tool for interdisciplinary assessment of coral reef processes. Coral Reefs 23, 1-4. https://doi.org/10.1007/s00338-003-0360-z

Andréfouët, S., Gu mar H.M., 2005. Coral reef distribution, status and geomorphology/biodiv ssity relationship in Kuna Yala (San Blas) archipelago, Caribbean Panama. Coral Reefs 24, 31-42.

Andréfouët, S., Wantiez, L., 2010. Characterizing the diversity of coral reef habitats and fish communities found in a UNESCO World Heritage Site: The strategy developed for Lagoons of New Caledonia. Marine Pollution Bulletin 61, 612-620.

Andréfouët, S., Hamel, M.A., 2014. Tropical islands quick data gap analysis guided by coral reef geomorphological maps. Marine Pollution Bulletin 81, 191-199.

Andréfouët, S., Berkelmans, R., Odriozola, L., Done, T., Oliver, J., Müller-Karger, F., 2002. Choosing the appropriate spatial resolution for monitoring coral bleaching events using remote sensing. Coral Reefs 21, 147-154.

Andréfouët, S., Kramer, P., Torres-Pulliza, D., Joyce, K.E., Hochberg, E.J., Garza-Pérez, R., 
Mumby, P.J., Riegl, B., Yamano, H., White, W.H., Zubia, M., Brock, J.C., Phinn, S.R., Naseer, A., Hatcher, B.G., Muller-Karger, F.E., 2003. Multi-site evaluation of IKONOS data for classification of tropical coral reef environments. Remote Sensing of Environment $88,128-143$.

Andréfouët, S., Muller-Karger, F.E., Robinson, J.A, Kranenburg, C.J., Torres-Pulliza, D., Spraggins, S.A, Murch, B., 2006. Global assessment of modern coral reef extent and diversity for regional science and management applications: a view from space. Proceeding of $10^{\text {th }}$ International Coral Reef Symposium, 1732-1745.

Andréfouët, S., Chauvin, C., Kranenburg, C., Muller-Karger, F.E., Noordeloos, M., 2008a, Atlas of South-East Papua New Guinea Coral Reefs, Centic IRD de Nouméa, Nouméa, Nouvelle-Calédonie. CD-ROM, pp; 40.

Andréfouët, S., Chagnaud, N., Chauvin, C., Kranenbur!r, S, 2008b. Atlas of the French

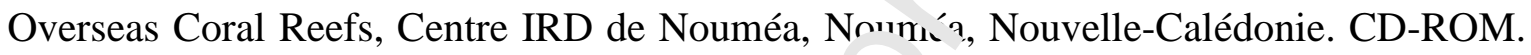
pp; 153.

Andréfouët, S., Chagnaud, N., Kranenburg, S, n09a. Atlas of the Central and Western Indian Ocean Coral Reefs, Centre IRD di Nouméa, Nouméa, Nouvelle-Calédonie. CDROM. pp. 157.

Andréfouët, S., Cabioch, G., Flamanı. B., Pelletier, B., 2009b. A reappraisal of the diversity of geomorphological and geneti $1 / 1$ nesses of New Caledonian coral reefs: a synthesis from optical remote sensing, cor' 'o and acoustic multibeam observations. Coral Reefs 28 , 691-707.

Andréfouët, S., Rilwan, Y., Hau uel, M.A., 2012. Habitat mapping for conservation planning in Baa Atoll, Republi : of Maldives. In: Biodiversity, Resources, and Conservation of Baa Atoll (Republic of M. ldives): A Unesco Man And Biosphere Reserve. Atoll Research Bulletin, 590 pp.

Andréfouët, S., Guillaume, M.M.M., Delval, A., Rasoamanendrika, F.M.A., Blanchot, J., Bruggemann, J.H., 2013. Fifty years of changes in reef flat habitats of the Grand Récif of Toliara (SW Madagascar) and the impact of gleaning. Coral Reefs 32, 757-768.

Andréfouët, S., Bruckner, A., Chabran, L., Campanozzi-Tarahu, J., Dempsey, A., 2014. Spread of the green snail Turbo marmoratus in French Polynesia 45 years after its introduction and implications for fishery management. Ocean \& Coastal Management 96, $42-50$.

Arvidson, T., Gasch, J., Goward, S.N., 2001. Landsat 7's long-term acquisition plan - an innovative approach to building a global imagery archive. Remote Sensing of 
Environment 78, 13-26.

Bell, J.D., Kronen, M., Vunisea, A., Nash, W.J., Keeble, G., Demmke, A., Pontifex, S., Andréfouët, S., 2009. Planning the use of fish for food security in the Pacific. Marine Policy 33, 64-76.

Bourrouilh-Le Jan, F.G., Talandier, J., 1985. Sédimentation et fracturation de haute énergie en milieu récifal: tsunamis, ouragans et cyclones et leurs effets sur la sédimentologie et la géomorphologie d'un atoll:motu et hoa, à Rangiroa, Tuamotu, Pacifique SE. Marine Geology 67, 263-333.

Boussarie, G., Bakker, J., Wangensteen, O.S., Mariani, S., Bonnin, L., Juhel, J.-B., Kiszka, J.J., Kulbicki, M., Manel, S., Robbins, W.D., Viglioía, L., Mouillot, D., 2018. Environmental DNA illuminates the dark diversity of shar s. S :i. Adv. 4, eaap9661.

Brown, C.J., Jupiter, S.D., Albert, S., Klein, C.J., Mangı bha , S., Maina, J.M., Mumby, P., Olley, J., Stewart-Koster, B., Tulloch, V., Wenger i , 2017. Tracing the influence of land-use change on water quality and coral reefs usin a Bayesian model. Sci Rep 7, 4740.

Bruckner, A., Rowlands, G., Riegl, B., Purkis, s., Villiams, A., Renaud, P., 2012. Khaled bin Sultan Living Oceans Foundation Atlas of saudi Arabian Red Sea Marine Habitats. Panoramic Press, pp. 262.

Burke, L., Maidens, 2004. Reefs at R. k in the Caribbean, World Resources Institute, pp. 84.

Carr, M.H., Robinson, S.P., Wahle (., Jjavis, G., Kroll, S., Murray, S., Schumacker, E.J., Williams, M., 2017. The cent al : mportance of ecological spatial connectivity to effective coastal marine protected $a_{1}$ 'as and to meeting the challenges of climate change in the marine environment. Aq. atic Conserv: Mar. Freshw. Ecosyst. 27, 6-29.

Cheok, J., Pressey, R.L W seks, R., Andréfouët, S., Moloney, J., 2016. Sympathy for the Devil: Detailing the E fects of Planning-Unit Size, Thematic Resolution of Reef Classes, and Socioeconomic Costs on Spatial Priorities for Marine Conservation. PLoS ONE 11, e0164869.

Cheok, J., Pressey, R.L., Weeks, R., VanDerWal, J., Storlie, C., 2018. The plans they are achangin': More frequent iterative adjustment of regional priorities in the transition to local actions can benefit implementation. Divers Distrib 24, 48-57.

Chollett, I., Mumby, P.J., 2012. Predicting the distribution of Montastraea reefs using wave exposure. Coral Reefs 31, 493-503.

Chollett, I., Garavelli, L., Holstein, D., Cherubin, L., Fulton, S., Box, S.J., 2017. A case for redefining the boundaries of the Mesoamerican Reef Ecoregion. Coral Reefs 36, 10391046. 
Cinner, J.E., et al.., 2018. Gravity of human impacts mediates coral reef conservation gains. Proc Natl Acad Sci USA 115, E6116-E6125.

Cohen, P.J., Cinner, J.E., Foale, S., 2013. Fishing dynamics associated with periodically harvested marine closures. Global Environmental Change 23, 1702-1713.

Cowen, R.K, Paris, C.B, Srinivasan, A. 2006. Scaling of connectivity in marine populations. Science 311, 522-527.

Cros, A., Venegas-Li, R., Teoh, S.J., Peterson, N., Wen, W., Fatan, N.A., 2014. Spatial Data Quality Control for the Coral Triangle Atlas. Coastal Management 42, 128-142.

CTI-CFF (Coral Triangle Initiative on coral reefs, Fisheries and food security), 2013. Coral Triangle marine protected area system framework and actı n plan. In. CTI-CFF, USA Agency for International Development Coral Triangle Sup ort Partnership and US NOAA Cebu City, Philippines, p. 75.

Dacks, R., Ticktin, T., Jupiter, S.D., Friedlander. 4., 2018. Drivers of fishing at the household scale in Fiji. Ecology and Society 23, arı.27.

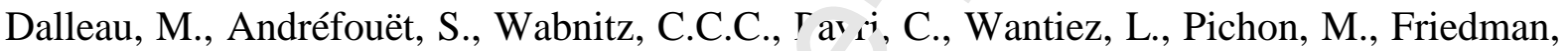
K., Vigliola, L., Benzoni, F., 2010. Use of Habitats as Surrogates of Biodiversity for Efficient Coral Reef Conservation $\mathrm{D} /$ nning in Pacific Ocean Islands. Conservation Biology 24, 541-552.

Deas, M., Andréfouët, S., Léopold N^. Guillemot, N., 2014. Modulation of Habitat-Based Conservation Plans by Fishery Lnportunity Costs: A New Caledonia Case Study Using Fine-Scale Catch Data. PLö ONE 9, e97409.

Derville, S., Torres, L.G., Tarı gue, C., 2018a. Social segregation of humpback whales in contrasted coastal anc oce inic breeding habitats. Journal of Mammalogy 99, 41-54.

Derville, S., Torres, L.G. Iovan, C., Garrigue, C., 2018b. Finding the right fit: Comparative cetacean distribution models using multiple data sources and statistical approaches. Divers Distrib 24, 1657-1673.

Doney, S.C., Ruckelshaus, M., Duffy, J.E., Barry, J.P., Chan, F., English, C.A., Galindo, H.M., Grebmeier, J.M., Hollowed, A.B., Knowlton, N., Polobina, J., Rabalais, N.N., Sydeman. W.J., Talley, L.D., 2012. Climate Change Impacts on Marine Ecosystems. Annual Review of Marine Science 4, 11-37.

Duvat, V.K.E., Salvat, B., Salmon, C., 2017. Drivers of shoreline change in atoll reef islands of the Tuamotu Archipelago, French Polynesia. Global and Planetary Change 158, 134154.

El Mahrad, B., Newton, A., Icely, J.D., Kacimi, I., Abalansa, S., Snoussi, M., 2020. 
Contribution of Remote Sensing Technologies to a Holistic Coastal and Marine Environmental Management Framework: A Review. Remote Sensing 12, 2313. https://doi.org/10.3390/rs12142313

Ferretti, F., Curnick, D., Liu, K., Romanov, E.V., Block, B.A., 2018. Shark baselines and the conservation role of remote coral reef ecosystems. Sci. Adv. 4, eaaq0333.

Foody, G.M., 2002. Status of land cover classification accuracy assessment. Remote Sensing of Environment 80, 185-201.

Foster, N.L., Paris, C.B., Kool, J.T., Baums, I.B., Stevens, J.R., Sanchez, J.A., Bastidas, C., Agudelo, C., Bush, P., Day, O., Ferrari, R., Gonzalez, P., Gore, S., Guppy, R., McCartney, M.A., McCoy, C., Mendes, J., Srinivasan, A., Steiner, S., Vermeij, M.J.A., Weil, E., Mumby, P.J., 2012. Connectivity of Caribbean coral popu'atic as: complementary insights from empirical and modelled gene flow. Molecular Ecc 'ogy 21, 1143-1157.

Freeman, L.A., Kleypas, J.A., Miller, A.J., 2013. Coral Reef Habitat Response to Climate Change Scenarios. PLoS ONE 8, e82404.

Gairin, E., Andréfouët, S., 2020. Role of habi dt definition on Aichi Target 11: Examples from New Caledonian coral reefs. Marine ז́ licy 116, 103951.

Garavelli, L., White, J.W., Chollett, I., Cıérubin, L.M., 2018. Population models reveal unexpected patterns of local pers - tence despite widespread larval dispersal in a highly

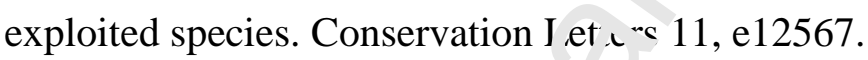

Govan H. et al. 2009. Status ar d r tential of locally-managed marine areas in the South

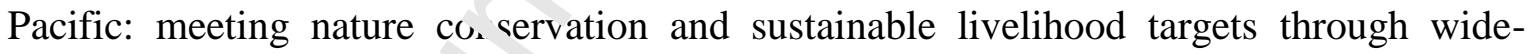

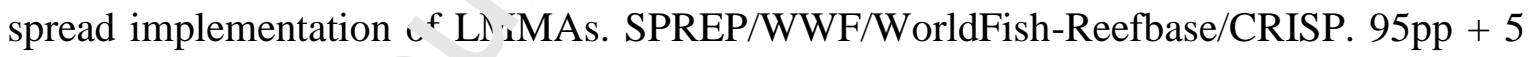
annexes

Green, A., Smith, S.E., L. psett-Moore, G., Groves, C., Peterson, N., Sheppard, S., Lokani, P., Hamilton, R., Almany, J., Aitsi, J., Bualia, L., 2009. Designing a resilient network of marine protected areas for Kimbe Bay, Papua New Guinea. Oryx 43, 488.

Hamel, M.A., Andréfouët, S., 2010. Using very high resolution remote sensing for the management of coral reef fisheries: Review and perspectives. Marine Pollution Bulletin 60, 1397-1405. https://doi.org/10.1016/j.marpolbul.2010.07.002

Hamel, M.A., Andréfouët, S., 2012. Biodiversity-based Propositions of Conservation Areas in Baa Atoll, Republic of Maldives. In: Biodiversity, Resources, and Conservation of Baa Atoll (Republic of Maldives): A Unesco Man And Biosphere Reserve. Atoll Research Bulletin, 590 pp.

Hamel, M.A., Andréfouët, S., Pressey, R.L., 2013. Compromises between international 
habitat conservation guidelines and small-scale fisheries in Pacific island countries: Conservation and fisheries in Pacific islands. Conservation Letters 6, 46-57.

Hamilton, R.J., Almany, G.R., Brown, C.J., Pita, J., Peterson, N.A., Howard Choat, J., 2017. Logging degrades nursery habitat for an iconic coral reef fish. Biological Conservation 210, 273-280.

Hamylton, S.M., 2017. Mapping coral reef environments: A review of historical methods, recent advances and future opportunities. Progress in Physical Geography: Earth and Environment 41, 803-833.

Hamylton, S., Andréfouët, S., 2013. An Appraisal of the Extent and Geomorphological Diversity of the Coral Reefs of the United Kingdom Depenunt Territories, in: Sheppard, C.R.C. (Ed.), Coral Reefs of the United Kingdom Overse s $_{\text {s }}$ tritories, Coral Reefs of the World. Springer Netherlands, Dordrecht, pp. 1-11. ttps //doi.org/10.1007/978-94-0075965-7_1

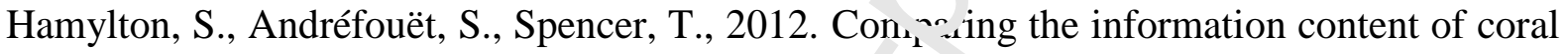
reef geomorphological and biological habita.r.aps, Amirantes Archipelago (Seychelles), Western Indian Ocean. Estuarine, Coastal a dd Snelf Science 111, 151-156.

Hedley, J.D., Roelfsema, C.M., Phinn, ¿ R., Mumby, P.J., 2012. Environmental and Sensor Limitations in Optical Remote St.sing of Coral Reefs: Implications for Monitoring and Sensor Design. Remote Sensing $/,]^{\prime} 1-302$.

Harborne, A.R., Green, A.L., P.te'nn, N.A., Beger, M., Golbuu, Y., Houk, P., Spalding, M.D., Taylor, B.M., Terk, I Treml, E.A., Victor, S., Vigliola, L., Williams, I.D., Wolff, N.H., zu Ermgassen, P.` E., Mumby, P.J., 2018. Modelling and mapping regional-scale patterns of fishing im act and fish stocks to support coral-reef management in Micronesia. Divers Distrib 24, 17' $\mathrm{L}$ - -1743.

Hochberg, E.J., Atkinson, M.J., Andréfouët, S., 2003. Spectral reflectance of coral reef bottom-types worldwide and implications for coral reef remote sensing. Remote Sensing of Environment 85, 159-173. https://doi.org/10.1016/S0034-4257(02)00201-8

Holstein, D., Paris, C., Mumby, P., 2014. Consistency and inconsistency in multispecies population network dynamics of coral reef ecosystems. Mar. Ecol. Prog. Ser. 499, 1-18. IPCC, 2014. Climate change 2014: synthesis report. In: Team C.W., Pachaury, R.K., L.A M. (Eds.), Contribution of Working Groups I, II and II to the Fifth Assessment Report of the Intergovernmental Panel on Climate Change. IPCC, Geneva, p. 151.

Jupiter, S.D., Epstein, G., Ban, N.C., Mangubhai, S., Fox, M., Cox, M., 2017. A SocialEcological Systems Approach to Assessing Conservation and Fisheries Outcomes in Fijian 
Locally Managed Marine Areas. Society \& Natural Resources 30, 1096-1111.

Kachelriess, D., Wegmann, M., Gollock, M., Pettorelli, N., 2014. The application of remote sensing for marine protected area management. Ecological Indicators 36, 169-177.

Kleypas, J.A., 1997. Modeled estimates of global reef habitat and carbonate production since the Last Glacial Maximum. Paleoceanography 12, 533-545.

Kool, J.T., Paris, C.B., Andréfouët, S., Cowen, R.K., 2010. Complex migration and the development of genetic structure in subdivided populations: an example from Caribbean coral reef ecosystems. Ecography 33, 597-606.

Kukkala, A.S., Moilanen, A., 2013. Core concepts of spatial prioritisation in systematic conservation planning: Concepts of systematic conservation ${ }^{1}{ }^{1}$ anning. Biol Rev 88, 443464.

Kutser, T., Hedley, J., Giardino, C., Roelfsema, C., Bran to, '.E., 2020. Remote sensing of shallow waters - A 50 year retrospective and fintu:e directions. Remote Sensing of Environment 240, 111619.

Lange, I.D., Perry, C.T., Alvarez-Filip, L., 24.20. Carbonate budgets as indicators of functional reef "health": A critical review $\mathrm{f}$ data underpinning census-based methods and current knowledge gaps. Ecological L. dir ators 110, 105857.

Letessier, T., Cox, M., Meeuwig, J., I nersch-Supan, P., Brierley, A., 2016. Enhanced pelagic biomass around coral atolls. Mar E..1 Prog. Ser. 546, 271-276.

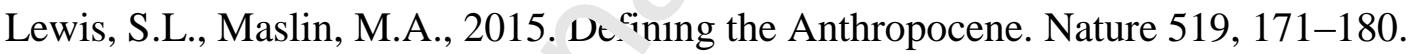

Li, J., Knapp, D.E., Fabina, i S., Kennedy, E.V., Larsen, K., Lyons, M.B., Murray, N.J., Phinn, S.R., Roelfsema, C.Ii., Asner, G.P., 2020. A global coral reef probability map generated using conv luti nal neural networks. Coral Reefs 39, 1805-1815.

Lindo-Atichati, D., Curc c, M., Paris, C.B., Buston, P.M., 2016. Description of surface transport in the region of the Belizean Barrier Reef based on observations and alternative high-resolution models. Ocean Modelling 106, 74-89.

Lipsett-Moore G, Hamilton R, Peterson N, Game E, Atu W, Kereseka J, Pita J, Ramohia P, Siota C., 2010. Ridges to Reefs Conservation Plan for Choiseul Province, Solomon Islands. TNC Pacific Islands Countries Report, No. 2/10, pp. 53.

Lyons, M., M. Roelfsema, C., V. Kennedy, E., M. Kovacs, E., Borrego-Acevedo, R., Markey, K., Roe, M., M. Yuwono, D., L. Harris, D., R. Phinn, S., Asner, G.P., Li, J., E. Knapp, D., S. Fabina, N., Larsen, K., Traganos, D., J. Murray, N., 2020. Mapping the world's coral reefs using a global multiscale earth observation framework. Remote Sens Ecol Conserv rse2.157. 
Maina, J., Jones, K., Hicks, C., McClanahan, T., Watson, J., Tuda, A., Andréfouët, S., 2015. Designing Climate-Resilient Marine Protected Area Networks by Combining Remotely Sensed Coral Reef Habitat with Coastal Multi-Use Maps. Remote Sensing 7, 1657116587.

Margules, C.R., Pressey, R.L., 2000. Systematic conservation planning. Nature 405, 243253.

McClanahan, T.R., Azali, M.K., 2020. Improving sustainable yield estimates for tropical reef fisheries. Fish Fish 21, 683-699.

McClenachan, L., O’Connor, G., Neal, B.P., Pandolfi, J.M., Jackson, J.B.C., 2017. Ghost reefs: Nautical charts document large spatial scale of coral n of loss over 240 years. Sci. Adv. 3, e1603155.

Melbourne-Thomas, J., Johnson, C.R., Fung, T., Seymı ur, R.M., Chérubin, L.M., AriasGonzález, J.E., Fulton, E.A., 2011. Regional-scale su`nario modeling for coral reefs: a

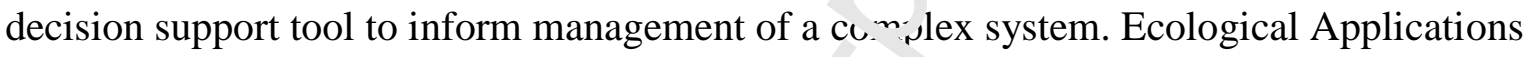
$21,1380-1398$.

Meltzner, A.J., Sieh, K., Abrams, M. i onew, D.C., Hudnut, K.W., Avouac, J.P., Natawidjaja, D.H., 2006. Uplift and $2 \mathrm{~b}$, idence associated with the great Aceh-Andaman earthquake of 2004. Journal of Ge, ,hysical Research-Solid Earth 111 : B2

Miller, K., Nand, Y., Mangubhai Ł., I_ee, S., Naisilisili, W., Sykes, H., 2018. Marine Biological Surveys of the No the "n Lau Group. Report No. 01/18. Vatuvara Foundation and the Wildlife Conservati $\eta$ Society, Suva, Fiji. 46 pp.

Mora, C., Andréfouët, S., Coste io, M.J., Kranenburg, C.J., Rollo, A., Veron, J.E.N., Gaston, K., Myers, R., 2006. Co al Reefs and the Global Network of Marine Protected Areas. Science 312, 1750-1\% 1 .

Moritz, C., Vii, J., Lee Long, W., Tamelander, J., Thomassin, A., Planes, S., 2018. Status and Trends of Coral Reefs of the Pacific. Global Coral Reef Monitoring Network.

Moses, C., Andréfouët, S., Kranenburg, C., Muller-Karger, F., 2009. Regional estimates of reef carbonate dynamics and productivity using Landsat $7 \mathrm{ETM}+$, and potential impacts from ocean acidification. Mar. Ecol. Prog. Ser. 380, 103-115.

Murray, N.J., Phinn, S.R., DeWitt, M., Ferrari, R., Johnston, R., Lyons, M.B., Clinton, N., Thau, D., Fuller, R.A., 2019. The global distribution and trajectory of tidal flats. Nature $565,222-225$.

Newton, K., Côté, I.M., Pilling, G.M., Jennings, S., Dulvy, N.K., 2007. Current and Future Sustainability of Island Coral Reef Fisheries. Current Biology 17, 655-658. 
NOAA., 2003. Atlas of the shallow-water benthic habitats of theNorthwestern Hawaiian Islands, p. 160

Pascal N, Leport G, Molisa V, Wendt H, Brander L,Fernandes L, Salcone J, Seidl A. 2015. National marine ecosystem service valuation: Vanuatu. Report MACBIO (GIZ/IUCN/SPREP): Suva, Fiji. p. 79.

Pearse, A.R., Hamilton, R.J., Choat, J.H., Pita, J., Almany, G., Peterson, N., Hamilton, G.S., Peterson, E.E., 2018. Giant coral reef fishes display markedly different susceptibility to night spearfishing. Ecol Evol 8, 10247-10256.

Perry, C.T., Spencer, T., Kench, P.S., 2008. Carbonate budgets and reef production states: a geomorphic perspective on the ecological phase-shift concep، Coral Reefs 27, 853-866.

Pinca, S., Kronen, M., Magron, F., McArdle, B., Vigliola, L . K ılbicki, M., Andréfouët, S., 2012. Relative importance of habitat and fishing in inflı encing reef fish communities across seventeen Pacific Island Countries and $7 c$-ritories: Habitat and fishing in influencing reef fish communities. Fish Fish 13, 30: 279.

Pinca, S., Kronen, M., Friedman K, Magron F, ı.hapman L, Tardy E, Pakoa K, Awira R, Boblin P, Lasi F., 2009. Regional assessme it report: profiles and results from survey work at 63 sites across 17 Pacific Islani Countries and Territories (1 March 2002 to 31 December 2009). Pacific Regi-nal Oceanic and Coastal Fisheries Development Programme, (PROCFish/C/CoFi h !' Secretariat of the Pacific Community, ISBN: 978982-00-0444-3, pp. 540.

Pinsky, M.L., Palumbi, S.R., ז`ndrefouët, S., Purkis, S.J., 2012. Open and closed seascapes: Where does habitat patc:ine is create populations with high fractions of self-recruitment? Ecological Applicatic ns 2 :, 1257-1267.

Pinsky, M.L., Saenz-Agı delo, P., Salles, O.C., Almany, G.R., Bode, M., Berumen, M.L., Andréfouët, S., Thorrold, S.R., Jones, G.P., Planes, S., 2017. Marine Dispersal Scales Are Congruent over Evolutionary and Ecological Time. Current Biology 27, 149-154.

Purkis, S.J., 2018. Remote Sensing Tropical Coral Reefs: The View from Above. Annu. Rev. Mar. Sci. 10, 149-168. https://doi.org/10.1146/annurev-marine-121916-063249

Reddy, S.M.W., Groves, T., Nagavarapu, S., 2014. Consequences of a GovernmentControlled Agricultural Price Increase on Fishing and the Coral Reef Ecosystem in the Republic of Kiribati. PLoS ONE 9, e96817.

Riegl, B.M., Sheppard, C.R.C., Purkis, S.J., 2012. Human Impact on Atolls Leads to Coral Loss and Community Homogenisation: A Modeling Study. PLoS ONE 7, e36921.

Rowlands, G., Purkis, S., Bruckner, A., 2014. Diversity in the geomorphology of shallow- 
water carbonate depositional systems in the Saudi Arabian Red Sea. Geomorphology 222, $3-13$.

Sale, P., Cowen, R., Danilowicz, B., Jones, G., Kritzer, J., Lindeman, K., Planes, S., Polunin, N., Russ, G., Sadovy, Y., 2005. Critical science gaps impede use of no-take fishery reserves. Trends in Ecology \& Evolution 20, 74-80.

Schill, S.R., Raber, G.T., Roberts, J.J., Treml, E.A., Brenner, J., Halpin, P.N., 2015. No Reef Is an Island: Integrating Coral Reef Connectivity Data into the Design of Regional-Scale Marine Protected Area Networks. PLoS ONE 10, e0144199.

Selkoe, K.A., Henzler, C.M., Gaines, S.D., 2008. Seascape genetics and the spatial ecology of marine populations. Fish and Fisheries 9, 363-377.

Silver, J.M., Arkema, K.K., Griffin, R.M., Lashley, B., Lemáv, N ., Maldonado, S., Moultrie, S.H., Ruckelshaus, M., Schill, S., Thomas, A., Wyatt, K., Verutes, G., 2019. Advancing Coastal Risk Reduction Science and Implementainn by Accounting for Climate, Ecosystems, and People. Front. Mar. Sci. 6, 556.

Scopélitis, J., Andréfouët, S., Phinn, S., Chab $\iota^{*}$ i P., Naim, O., Tourrand, C., Done, T., 2009. Changes of coral communities over' 5 years: Integrating in situ and remote-sensing data on Saint-Leu Reef (la Réunion, 'nd an Ocean). Estuarine, Coastal and Shelf Science 84, 342-352.

Scopélitis, J., Andréfouët, S., Phinn S, none, T., Chabanet, P., 2011. Coral colonisation of a shallow reef flat in response $\iota_{0}$ 'sing sea level: quantification from 35 years of remote sensing data at Heron Islanc; Australia. Coral Reefs 30, 951-965.

Smallhorn-West, P.F., Gor'`n, j.E., Dempsey, A.C., Purkis, S.J., Malimali, S., Halafihi, T., Southgate, P.C., Br dge. T.C.L., Pressey, R.L., Jones, G.P., 2020. Tongan socioenvironmental spatial layers for marine ecosystem management. Pac. Conserv. Biol. https://doi.org/10.1071/PC19032

Smith, S.V., 1978. Coral-reef area and the contributions of reefs to processes and resources of the world's oceans. Nature 273, 225-226.

Spalding, M.D., Ravilious, C., Green, E.P., 2001. World Atlas of Coral Reefs. Prepared at the UNEP World Conservation Monitoring Centre. University of California Press, Berkeley, USA.

Torres-Pulliza, D., Wilson, J.R., Darmawan, A., Campbell, S.J., Andréfouët, S., 2013. Ecoregional scale seagrass mapping: A tool to support resilient MPA network design in the Coral Triangle. Ocean \& Coastal Management 80, 55-64.

Tulloch, V.J.D., Brown, C.J., Possingham, H.P., Jupiter, S.D., Maina, J.M., Klein, C., 2016. 
Improving conservation outcomes for coral reefs affected by future oil palm development in Papua New Guinea. Biological Conservation 203, 43-54.

Turner, W., Spector, S., Gardiner, N., Fladeland, M., Sterling, E., Steininger, M., 2003.

Remote sensing for biodiversity science and conservation. Trends in Ecology \& Evolution $18,306-314$.

van Hooidonk, R., Maynard, J.A., Planes, S., 2013. Temporary refugia for coral reefs in a warming world. Nature Climate Change 3, 508-511.

van Hooidonk, R., Maynard, J.A., Manzello, D., Planes, S., 2014. Opposite latitudinal gradients in projected ocean acidification and bleaching impacts on coral reefs. Glob Change Biol 20, 103-112.

Van Wynsberge, S., Andréfouët, S., Hamel, M.A., Kulbicki, . 1., ' 012. Habitats as Surrogates of Taxonomic and Functional Fish Assemblages in ('ora Reef Ecosystems: A Critical Analysis of Factors Driving Effectiveness. PLoS ONL ? e40997.

Van Wynsberge, S., Andréfouët, S., Gaertner-M.'suni, N., Remoissenet, G., 2015. Conservation and resource management in st.all tropical islands: Trade-offs between planning unit size, data redundancy and da’ loss. Ocean \& Coastal Management 116, 3743.

Van Wynsberge, S., Andréfouët, S. Gaertner-Mazouni, N., Tiavouane, J., Grulois, D., Lefèvre, J., Pinsky, M.L., Fauv :IC ‘, r., 2017. Considering reefscape configuration and composition in biophysical mode advance seascape genetics. PLoS ONE 12, e0178239.

Vecsei, A., 2004. A new estiı ate of global reefal carbonate production including the forereefs. Global and Planet."v C uange 43, 1-18.

Veettil, B.K., Ward, R.I '., L ma, M.D.A.C., Stankovic, M., Hoai, P.N., Quang, N.X., 2020. Opportunities for sea rass research derived from remote sensing: A review of current methods. Ecological Indicators 117, 106560.

Wabnitz, C.C., Andréfouët, S., Muller-Karger, F.E., 2010. Measuring progress toward global marine conservation targets. Frontiers in Ecology and the Environment 8, 124-129.

Wabnitz, C.C., Andréfouët, S., Torres-Pulliza, D., Müller-Karger, F.E., Kramer, P.A., 2008. Regional-scale seagrass habitat mapping in the Wider Caribbean region using Landsat sensors: Applications to conservation and ecology. Remote Sensing of Environment 112, 3455-3467.

Wang, L., Jia, M., Yin, D., Tian, J., 2019. A review of remote sensing for mangrove forests: 1956-2018. Remote Sensing of Environment 231, 111223.

Weeks, R., Jupiter, S.D., 2013. Adaptive Comanagement of a Marine Protected Area 
Network in Fiji. Conservation Biology 27, 1234-1244.

Weeks, R., Green, A.L., Joseph, E., Peterson, N., Terk, E., 2017. Using reef fish movement to inform marine reserve design. J Appl Ecol 54, 145-152.

Weeks, R., 2017. Incorporating seascape connectivity in conservation prioritisation. PLoS ONE 12, e0182396.

Williams, S.M., Sánchez-Godínez, C., Newman, S.P., Cortés, J., 2017. Ecological assessments of the coral reef communities in the Eastern Caribbean and the effects of herbivory in influencing coral juvenile density and algal cover. Mar Ecol 38, e12395.

White, A.T., Aliño, P.M., Cros, A., Fatan, N.A., Green, A.L., Teoh, S.J., Laroya, L., Peterson, N., Tan, S., Tighe, S., Venegas-Li, R., Walton, i . Wen, W., 2014. Marine Protected Areas in the Coral Triangle: Progress, Issues, an 1 Or tions. Coastal Management 42, 87-106.

Wright, S., 1946. Isolation by distance under diverse svote.ns of mating. Genetics 31, 39-59.

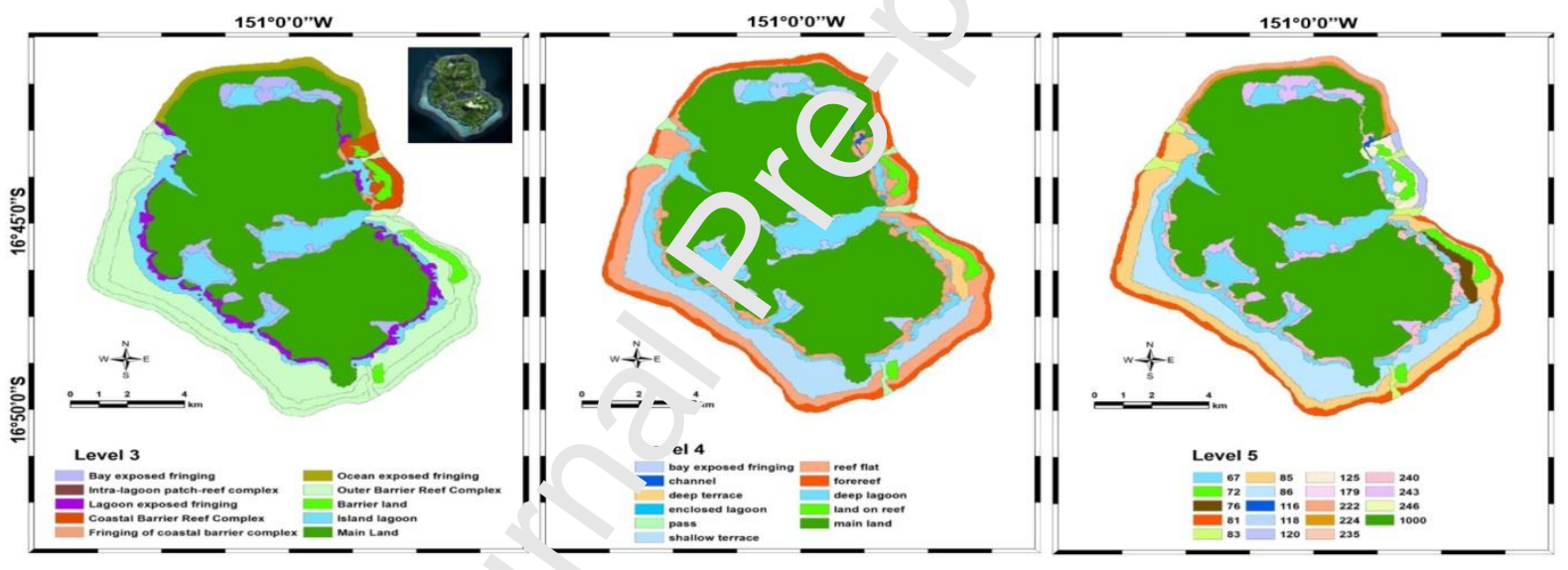

Figure 1: Map of Huahine (Fre ch Polynesia) showing MCRMP geomorphologic classes at Level 3 (left), 4 (mirdlı), a d 5 (right). Satellite imagery of Huahine is shown on the first map. Huahine is a $140 \mathrm{k} \mathrm{n}^{2}$ island, and is at the lower limit of the application domain of MCRMP, A typical application would be to compare several islands like Huahine within an archipelago. However, even for a single island like Huahine, it is possible to infer a stratified sampling scheme based on the map and compare surface areas of the different classes. Huahine is a (Level 1) oceanic (Level 2) island. Hence, all reef classes down the hierarchy also correspond to an 'oceanic island'. At Level 5, the codes refer to the following classes (with names displayed as follows: Level 3 - Level 4): 67: island lagoon - deep lagoon; 72: barrier land - land on reef; 76: outer barrier reef complex - deep terrace; 81: outer barrier reef complex - forereef; 83: outer barrier reef complex - pass; 85: outer barrier reef complex - reef flat; 86: outer barrier reef complex - shallow terrace; 116: coastal barrier reef complex - channel; 118: coastal barrier reef complex - enclosed lagoon; 120: coastal barrier reef 
complex - forereef; 125: coastal barrier reef complex - reef flat; 179: intra-lagoon patch-reef complex - reef flat; 222: ocean exposed fringing - forereef; 224: ocean exposed fringing reef flat; 235: lagoon exposed fringing - channel; 240: lagoon exposed fringing - reef flat; 243: bay exposed fringing - bay exposed fringing; 246: fringing of coastal barrier complex reef flat; 1000: main land - main land.

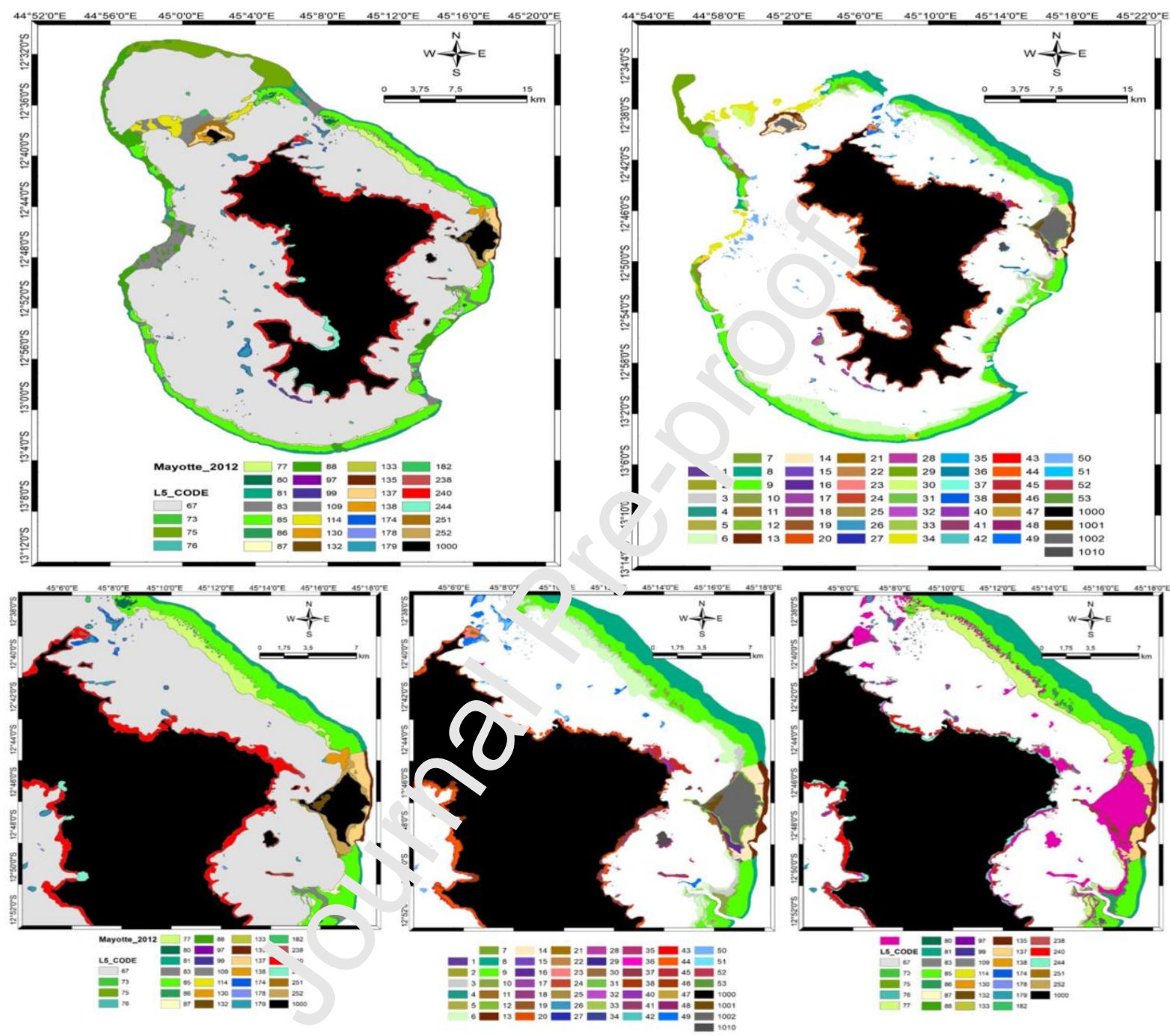

Figure 2: Top panel: For Mayotte Island in the Mozambique Chanel, Western Indian Ocean, comparison between MCRMP (version 2012) from Landsat images at 30m resolution (left) (Andréfouët et al. 2008) and geomorphological map based on very high resolution 2 meter remote sensing images (right). Bottom: enlarged views representing the same products (Left : MCRMP; center: high resolution product) while the right panel shows in magenta color the areas that have additional hierarchical description compared to MCRMP. The high-resolution product follows the same principles as MCRMP and does not require ground-truth data. It also uses the same hierarchical typology of MCRMP but expands it with additional classes that can be mapped only at high spatial resolution. The spatial details are also improved for all classes. Processing time is increased $\sim 10$ times between products. Note that on this map the deep lagoon and passes are not shown for the high resolution product. The north of the reef is also not shown since no image was purchased for this area. MCRMP data includes 32 classes, versus 64 for the high resolution products $(62+$ deep lagoon+ passes). Classes are described in Tables S1 and S2. 
Table 1: Summary table compiling 62 studies that have used MCRMP data for a variety of applications, sites and levels of description. The references are sorted by chronological order of their year of publication. MCRMP: Millennium Coral Reef Mapping Project; PICT= Pacific Island Countries and Territories. The correspondences between the topics in the table and the sections in the main text (cf. Discussion) are: Inventory/Visualization ='MCRMP for coral reef visualization and inventories'; Conservation = 'MCRMP for conservation planning', 'Ecology' = MCRMP to enhance the spatial description of coral reef biodiversity and ecological processes, Fisheries = 'MCRMP for fishery resource assessment'; Other ecosystems $=$ 'Incidental benefits of MCRMP products for the description of other ecosystems and the study of non-coral reef species'; Connectivity = 'MCRMP to model connectivity'; Future reefs = 'MCRMP and the modeling of future reefs in a climate change era', Geology, Physical oceanography and socio-economy represent 'MCRMP for other topical studies'

\begin{tabular}{|c|c|c|c|c|c|}
\hline ID & Reference & Summary & Topics & Location & Level \\
\hline 1 & $\begin{array}{l}\text { Andréfouët } \\
\text { and Guzman } \\
(2005)\end{array}$ & $\begin{array}{l}\text { Use prototype } \\
\text { MCRMP product } \\
\text { from San Blas } \\
\text { Archipelago to } \\
\text { compare } \\
\text { geomorphology } \\
\text { and biological } \\
\text { benthic richness }\end{array}$ & Ecology & Panama & L5 \\
\hline 2 & $\begin{array}{l}\text { Andréfouët et } \\
\text { al. (2006a) }\end{array}$ & $\begin{array}{l}\text { Presentation of } \\
\text { MCRMP and firs. } \\
\text { results }\end{array}$ & $\operatorname{In} t \cdot 10^{\prime} y$ & Global & L1-L5 \\
\hline 3 & $\begin{array}{l}\text { Andréfouët et } \\
\text { al. (2006b) }\end{array}$ & $\begin{array}{l}\text { Atlas of Prnum } \\
\text { New Guinen c or } 1 \text { l } \\
\text { reefs }\end{array}$ & Inventory/Visualization & $\begin{array}{l}\text { Papua New } \\
\text { Guinea }\end{array}$ & L1-L5 \\
\hline 4 & $\begin{array}{lll}\text { Mora et al } \\
(2006) & \end{array}$ & $\begin{array}{l}\text { Gap a alysis in } \\
\text { co su vation of } \\
\text { crat reefs } \\
\text { Wurldwide }\end{array}$ & Conservation & Global & $\mathrm{REEF}=1$ \\
\hline 5 & $\begin{array}{l}\text { Allain et al. } \\
(2008)\end{array}$ & $\begin{array}{l}\text { Enhance } \\
\text { seamounts spatial } \\
\text { database }\end{array}$ & Other ecosystems & $\begin{array}{l}\text { Central and } \\
\text { West } \\
\text { Pacific } \\
\text { Ocean }\end{array}$ & $\mathrm{REEF}=1$ \\
\hline 6 & $\begin{array}{l}\text { Andréfouët et } \\
\text { al. (2008) }\end{array}$ & $\begin{array}{l}\text { Atlas of Caribbean, } \\
\text { Indian and Pacific } \\
\text { Ocean French reefs } \\
\text { s }\end{array}$ & Inventory/Visualization & France & L1-L5 \\
\hline 7 & $\begin{array}{l}\text { Green et al. } \\
(2008)\end{array}$ & $\begin{array}{l}\text { Using a resilience } \\
\text { framework, design } \\
\text { a network of MPAs }\end{array}$ & Conservation & $\begin{array}{l}\text { Papua New } \\
\text { Guinea }\end{array}$ & L4 \\
\hline
\end{tabular}




\begin{tabular}{|c|c|c|c|c|c|}
\hline & & $\begin{array}{l}\text { based } \\
\text { distribution on } \\
\text { habitat types and } \\
\text { spatialzed } \\
\text { biodiversity layers } \\
\text { using MCRMP }\end{array}$ & & & \\
\hline 8 & $\begin{array}{l}\text { Wabnitz et al. } \\
\text { (2008) }\end{array}$ & $\begin{array}{l}\text { Use of MCRMP to } \\
\text { stratify the } \\
\text { mapping } \\
\text { shallow seagrass } \\
\text { beds }\end{array}$ & Other ecosystem & Caribbean & L4 \\
\hline 9 & $\begin{array}{l}\text { Andréfouët et } \\
\text { al. (2009a) }\end{array}$ & $\begin{array}{l}\text { Link } \\
\text { geomorphology of } \\
\text { modern reefs to } \\
\text { geodynamic } \\
\text { processes, from } \\
125 \mathrm{ka} \text { ago to } \\
\text { present }\end{array}$ & Geology & $\begin{array}{l}\text { New } \\
\text { Caledonia }\end{array}$ & L1-L5 \\
\hline 10 & $\begin{array}{l}\text { Andréfouët et } \\
\text { al. (2009b) }\end{array}$ & $\begin{array}{l}\text { Atlas of Central } \\
\text { and Western Indian } \\
\text { Ocean coral reefs }\end{array}$ & Invertiry & $\begin{array}{l}\text { Central and } \\
\text { Western } \\
\text { Indian } \\
\text { Ocean }\end{array}$ & L1-L5 \\
\hline 11 & $\begin{array}{l}\text { Bell et al. } \\
(2009)\end{array}$ & $\begin{array}{l}\text { Scaling-up fish } \\
\text { biomass to as ass } \\
\text { food securit ol } \\
\text { PICT in the fut re }\end{array}$ & $\begin{array}{l}\text { Fisheries } \\
\text { Future reefs }\end{array}$ & $\begin{array}{l}\text { Pacific } \\
\text { Ocean }\end{array}$ & $\begin{array}{l}\mathrm{REEF}=1 ; \\
\text { lagoons }\end{array}$ \\
\hline 12 & $\begin{array}{l}\text { Moses et al. } \\
(2009)\end{array}$ & $\begin{array}{l}\text { Scaling-up Furida } \\
\text { reef me abolic } \\
\text { perforn.nces at } \\
\text { prese }{ }^{+} \text {and in } \\
\text { fu ure ime }\end{array}$ & Future reefs & $\begin{array}{l}\text { United } \\
\text { States }\end{array}$ & L4 \\
\hline 13 & $\begin{array}{l}\text { Pinca et al. } \\
(2009)\end{array}$ & $\begin{array}{lr}n_{L_{r}} i n g & \text { strategy } \\
\text { for reef } & \text { fishery } \\
\text { assessment r of } \\
\text { PICT (one report } \\
\text { per country) }\end{array}$ & Fishery & $\begin{array}{l}\text { Pacific } \\
\text { Ocean }\end{array}$ & L3/L4 \\
\hline 14 & $\begin{array}{l}\text { Andréfouët } \\
\text { and Wantiez } \\
(2010)\end{array}$ & $\begin{array}{l}\text { Sampling strategy } \\
\text { for monitoring } \\
\text { UNESCO World } \\
\text { Heritage Lagoons } \\
\text { of New Caledonia } \\
\text { conservation areas }\end{array}$ & $\begin{array}{l}\text { Ecology } \\
\text { Conservation }\end{array}$ & $\begin{array}{l}\text { New } \\
\text { Caledonia }\end{array}$ & L5 \\
\hline 15 & $\begin{array}{l}\text { Kool et al. } \\
(2010)\end{array}$ & $\begin{array}{l}\text { Spatial gene flow } \\
\text { model in the } \\
\text { Caribbean taking } \\
\text { into account } \\
\text { habitats }\end{array}$ & Connectivity & Caribbean & L4 \\
\hline
\end{tabular}




\begin{tabular}{|c|c|c|c|c|c|}
\hline 16 & $\begin{array}{l}\text { Lipsett-Moore } \\
\text { et al. (2010) }\end{array}$ & $\begin{array}{l}\text { Identification of } \\
\text { conservation } \\
\text { priority areas }\end{array}$ & Conservation & $\begin{array}{l}\text { Solomon } \\
\text { Islands }\end{array}$ & L4 \\
\hline 17 & $\begin{array}{l}\text { Wabnitz et al. } \\
(2010)\end{array}$ & $\begin{array}{l}\text { Call for } \\
\text { enhancement } \\
\text { mapping of coral } \\
\text { reefs and compare } \\
\text { reef areas provided } \\
\text { by different } \\
\text { sources }\end{array}$ & Inventory & Global & $\mathrm{REEF}=1$ \\
\hline 18 & $\begin{array}{l}\text { Melbourne- } \\
\text { Thomas et al. } \\
(2011)\end{array}$ & $\begin{array}{l}\text { To predict future } \\
\text { coral reef states } \\
\text { following land-use } \\
\text { and } \\
\text { changes }\end{array}$ & Future reefs & $\begin{array}{l}\text { Meso- } \\
\text { America }\end{array}$ & $\mathrm{REEF}=1$ \\
\hline 19 & $\begin{array}{l}\text { Allain et al. } \\
(2012)\end{array}$ & $\begin{array}{l}\text { Assess the } \\
\text { relationship } \\
\text { between coastal } \\
\text { and ocean } \\
\text { ecosystems } \\
\text { through predators } \\
\text { stomach contents } \\
\text { and their distance } \\
\text { to land and reefs }\end{array}$ & $\begin{array}{l}\text { Other ecosy } \\
\text { Ecology } \\
\text { Fishery }\end{array}$ & $\begin{array}{l}\text { Central and } \\
\text { West } \\
\text { Pacific } \\
\text { Ocean }\end{array}$ & $\mathrm{REEF}=1$ \\
\hline 20 & $\begin{array}{l}\text { Allnutt et al. } \\
(2012)\end{array}$ & 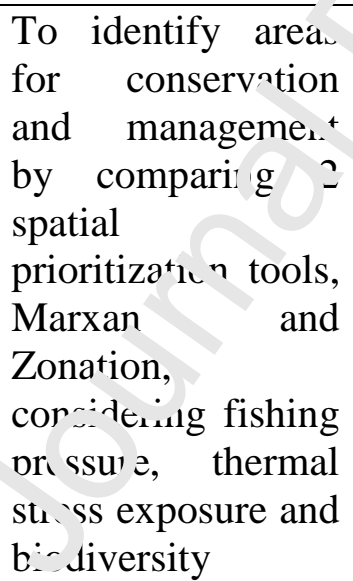 & $\begin{array}{l}\text { Conservation } \\
\text { I ature reefs } \\
\text { Fishery }\end{array}$ & Madagascar & $\mathrm{REEF}=1$ \\
\hline 21 & $\begin{array}{l}\text { Hamel and } \\
\text { Andréfouët } \\
(2012)\end{array}$ & $\begin{array}{l}\text { Proposition of } \\
\text { zoning plan for } \\
\text { Baa Atoll }\end{array}$ & Conservation & Maldives & L4 \\
\hline 22 & $\begin{array}{l}\text { Chollett and } \\
\text { Mumby } \\
(2012)\end{array}$ & $\begin{array}{l}\text { Identification of } \\
\text { Orbicella reefs } \\
\text { distribution on } \\
\text { Meso-America } \\
\text { forereefs }\end{array}$ & Ecology & $\begin{array}{l}\text { Mexico, } \\
\text { Belize }\end{array}$ & L4 \\
\hline 23 & Pinca et al. & Interpretation of & Fisheries & Pacific & L3-L4 \\
\hline
\end{tabular}




\begin{tabular}{|c|c|c|c|c|c|}
\hline & (2012) & $\begin{array}{l}\text { reef } \\
\text { geomorphology for } \\
\text { fishery data } \\
\text { analysis in PICT }\end{array}$ & & Ocean & \\
\hline 24 & $\begin{array}{l}\text { Foster et al. } \\
(2012)\end{array}$ & $\begin{array}{l}\text { Compare results } \\
\text { from Kool et al. } \\
(2010) \quad \text { with } \\
\text { biophysical models } \\
\text { and genetics data } \\
\text { for a Caribbean } \\
\text { coral }\end{array}$ & Connectivity & Caribbean & $\begin{array}{l}\text { REEF=1; } \\
\text { UNEP- } \\
\text { WCMC }\end{array}$ \\
\hline 25 & $\begin{array}{l}\text { Hamylton et } \\
\text { al. (2012) }\end{array}$ & $\begin{array}{l}\text { Compare the } \\
\text { information } \\
\text { content of } \\
\text { geomorphological } \\
\text { (MCRMP) and } \\
\text { biological habitat } \\
\text { maps in the } \\
\text { Admirantes Group. }\end{array}$ & Inventory/Visualiza ${ }^{\circ}$ on & Seychelles & $\mathrm{L} 4$ \\
\hline 26 & $\begin{array}{l}\text { Pinsky et al. } \\
(2012)\end{array}$ & $\begin{array}{l}\text { Define opened or } \\
\text { closed populations } \\
\text { according to larvaf } \\
\text { dispersal anc } \\
\text { spacing between } \\
\text { habitat patches }\end{array}$ & Cor ne tivity & $\begin{array}{l}\text { Bahamas, } \\
\text { Papua New } \\
\text { Guinea, } \\
\text { others }\end{array}$ & $\mathrm{REEF}=1$ \\
\hline 27 & $\begin{array}{l}\text { Riegl et al. } \\
(2012)\end{array}$ & 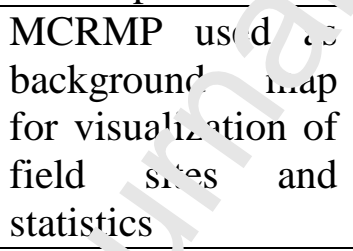 & Visualization & $\begin{array}{l}\text { Chagos, } \\
\text { UK }\end{array}$ & $\mathrm{REEF}=1$ \\
\hline 28 & $\begin{array}{l}\text { Cohen et al. } \\
(2013)\end{array}$ & $\begin{array}{l}\text { Ascs } \\
\text { pe iod cally } \\
\text { havest closures to } \\
\text { r. intain fishery } \\
\text { resources }\end{array}$ & Fishery & $\begin{array}{l}\text { Solomon } \\
\text { Islands }\end{array}$ & Unclear \\
\hline 29 & $\begin{array}{l}\text { Deas et al. } \\
(2013)\end{array}$ & $\begin{array}{l}\text { Sensitivity analysis } \\
\text { of conservation } \\
\text { solutions to habitat } \\
\text { maps and a variety } \\
\text { of fishery } \\
\text { opportunity costs }\end{array}$ & $\begin{array}{l}\text { Conservation } \\
\text { Fishery } \\
\text { Representation }\end{array}$ & $\begin{array}{l}\text { New } \\
\text { Caledonia }\end{array}$ & L5 \\
\hline 30 & $\begin{array}{l}\text { Hamel et al. } \\
(2013)\end{array}$ & $\begin{array}{l}\text { Assess trade-offs } \\
\text { between } \\
\text { conservation } \\
\text { objectives (habitat } \\
\text { representation)and } \\
\text { fishery opportunity } \\
\text { costs }\end{array}$ & Conservation & $\begin{array}{l}\text { Wallis and } \\
\text { Futuna }\end{array}$ & L3-L5 \\
\hline
\end{tabular}




\begin{tabular}{|c|c|c|c|c|c|}
\hline 31 & $\begin{array}{l}\text { Hamylton and } \\
\text { Andréfouët } \\
\text { (2013) }\end{array}$ & 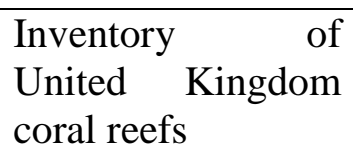 & Inventory & UK & L2-L5 \\
\hline 32 & $\begin{array}{l}\text { Torres-Pulliza } \\
\text { et al. (2013) }\end{array}$ & $\begin{array}{l}\text { Enhance seagrass } \\
\text { mapping using } \\
\text { MCRMP strata and } \\
\text { conservation plans } \\
\text { using coral reef } \\
\text { habitat } \\
\text { representation } \\
\text { under a resilience } \\
\text { framework for the } \\
\text { Lesser Sunda } \\
\text { ecoregion }\end{array}$ & $\begin{array}{l}\text { Other ecosystems } \\
\text { Conservation }\end{array}$ & Indonesia & $\mathrm{L} 4$ \\
\hline 33 & $\begin{array}{l}\text { Weeks and } \\
\text { Jupiter (2013) }\end{array}$ & & $\begin{array}{l}\text { Conservation } \\
\text { Fishery }\end{array}$ & Fiji & $\mathrm{L} 4$ \\
\hline 34 & $\begin{array}{l}\text { Andréfouët } \\
\text { and Hamel } \\
(2014)\end{array}$ & $\begin{array}{lr}\text { Conservation } & \text { and } \\
\text { research } & \text { gap } \\
\text { analyses } & \text { using } \\
\text { MCRMP } & \text { products } \\
\text { and } & \text { metadata } \\
\text { inventories } & \\
\end{array}$ & Conservation & $\begin{array}{l}\text { Solomon } \\
\text { Islands }\end{array}$ & L5 \\
\hline 35 & $\begin{array}{l}\text { Dacks et al. } \\
(2014)\end{array}$ & 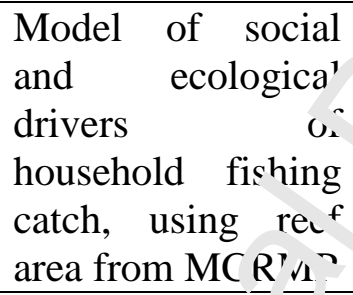 & $\mathrm{Fi}, \mathrm{h} \mathrm{C}_{\mathrm{i}, \mathrm{z}}$ & Fiji & Unclear \\
\hline 36 & $\begin{array}{l}\text { Reddy et al. } \\
(2014)\end{array}$ & $\begin{array}{l}\text { Highlight livW } \\
\text { changing copra } \\
\text { price in } .^{-1} \text { and can } \\
\text { impart marine } \\
\text { ecrslu.l services }\end{array}$ & Socio-economy & Kiribati & L4 \\
\hline 37 & $\begin{array}{l}\text { Maina et al. } \\
(2015)\end{array}$ & $\begin{array}{l}\mathrm{Cc} \text { nse' vation, } \\
\text { mı'ti-criteria, } \\
\mathrm{f}_{2} \text {...nework to } \\
\text { assess solution } \\
\text { resilient to climate } \\
\text { change and fishery } \\
\text { exploitation }\end{array}$ & $\begin{array}{l}\text { Future reefs } \\
\text { Fishery } \\
\text { Conservation }\end{array}$ & Kenya & L3 \\
\hline 38 & $\begin{array}{l}\text { Letessier et al. } \\
\text { (2016) }\end{array}$ & $\begin{array}{l}\text { Assess fish } \\
\text { biomass and } \\
\text { ecological } \\
\text { interaction between } \\
\text { deep and mid- } \\
\text { waters } \\
\text { communities } \\
\text { around coral atolls }\end{array}$ & $\begin{array}{l}\text { Other ecosystems } \\
\text { Fishery }\end{array}$ & $\begin{array}{l}\text { Chagos, } \\
\text { UK }\end{array}$ & $\mathrm{REEF}=1$ \\
\hline 39 & $\begin{array}{l}\text { Cheok et al. } \\
(2016)\end{array}$ & $\begin{array}{l}\text { Assess the effects } \\
\text { of planning units }\end{array}$ & Conservation & $\begin{array}{l}\text { Fiji, } \\
\text { Federate }\end{array}$ & L1-L5 \\
\hline
\end{tabular}




\begin{tabular}{|c|c|c|c|c|c|}
\hline & & $\begin{array}{l}\text { size, } \\
\text { geomorphological } \\
\text { levels and cost } \\
\text { (individually and } \\
\text { together) } \\
\text { conservation } \\
\text { solution }\end{array}$ & & $\begin{array}{l}\text { States of } \\
\text { Micronesia }\end{array}$ & \\
\hline 40 & $\begin{array}{l}\text { Lindo-Atichati } \\
\text { et al. (2016) }\end{array}$ & $\begin{array}{l}\text { Enhancement of } \\
\text { reef representation } \\
\text { in physical } \\
\text { oceanography } \\
\text { model }\end{array}$ & Physical oceanography & $\begin{array}{l}\text { Meso- } \\
\text { America }\end{array}$ & Depth \\
\hline 41 & $\begin{array}{l}\text { Tulloch et al. } \\
\text { (2016) }\end{array}$ & $\begin{array}{l}\text { Model high } \\
\text { priority areas for } \\
\text { marine } \\
\text { conservation, } \\
\text { considering the } \\
\text { impact of oil palm } \\
\text { agriculture }\end{array}$ & Conservation & $\begin{array}{l}\text { Papua New } \\
\text { Guinea }\end{array}$ & L4 \\
\hline 42 & $\begin{array}{l}\text { Weeks et al. } \\
(2016)\end{array}$ & $\begin{array}{l}\text { Suggest } \\
\text { conservation } \\
\text { solutions for } \\
\text { selected fish } \\
\text { species in Pohnpe } \\
\text { Island }\end{array}$ & $\begin{array}{l}\text { Conservation } \\
\text { Fishery }\end{array}$ & $\begin{array}{l}\text { Federate } \\
\text { States of } \\
\text { Micronesia }\end{array}$ & L4 \\
\hline 43 & $\begin{array}{l}\text { Hamilton et al. } \\
\text { (2017) }\end{array}$ & $\begin{array}{l}\text { Assess the imnact } \\
\text { of logging on } ~ \\
\text { muricatum } \\
\text { juvenile's atiat } \\
\text { and its e ect on } \\
\text { juveniles } \\
\text { abundanc. }\end{array}$ & $\begin{array}{l}\text { Ïshery } \\
\text { Ecology }\end{array}$ & $\begin{array}{l}\text { Solomon } \\
\text { Islands }\end{array}$ & L3-4 \\
\hline 44 & $\begin{array}{l}\text { Jupiter et al. } \\
(2017)\end{array}$ & $\begin{array}{lr}\text { Ide-tity the main } \\
\text { factors affecting } \\
\text { re unces } \\
\text { andiversity } \\
\text { conservation } \\
\text { several in } \\
\text { LMMAs }\end{array}$ & $\begin{array}{l}\text { Connectivity } \\
\text { Conservation }\end{array}$ & Fiji & L3 \\
\hline 45 & $\begin{array}{l}\text { McClenachan } \\
\text { et al. (2017) }\end{array}$ & $\begin{array}{l}\text { Assess the loss of } \\
\text { coral reef habitats } \\
\text { from 18th century } \\
\text { to present in } \\
\text { Florida Keys }\end{array}$ & $\begin{array}{l}\text { Inventory } \\
\text { Ecology }\end{array}$ & $\begin{array}{l}\text { United } \\
\text { States }\end{array}$ & L4 \\
\hline 46 & $\begin{array}{l}\text { Van } \\
\text { Wynsberge et } \\
\text { al. (2017) }\end{array}$ & $\begin{array}{l}\text { Assess the genetic } \\
\text { structure of giant } \\
\text { clam Tridacna } \\
\text { maxima in the } \\
\text { Coral Sea }\end{array}$ & Connectivity & $\begin{array}{l}\text { New } \\
\text { Caledonia, } \\
\text { Vanuatu }\end{array}$ & L1-3 \\
\hline 47 & Williams et al. & Assess the effect of & Ecology & America & L5 \\
\hline
\end{tabular}




\begin{tabular}{|c|c|c|c|c|c|}
\hline & (2017) & $\begin{array}{lr}\text { Orbicella } & \text { reef } \\
\text { status on } & \text { coral } \\
\text { recruitment } & \text { and } \\
\text { algal cover } & \\
\end{array}$ & & $\begin{array}{l}\text { Eastern } \\
\text { Caribbean }\end{array}$ & \\
\hline 48 & Weeks (2017) & $\begin{array}{ll}\text { Identify } & \\
\text { conservation areas } \\
\text { using connectivity } \\
\text { between adult and } \\
\text { juveniles fish } \\
\text { habitats }\end{array}$ & $\begin{array}{l}\text { Connectivity } \\
\text { Ecology }\end{array}$ & $\begin{array}{l}\text { Micronesia } \\
-\quad \text { Yap } \\
\text { Proper }\end{array}$ & L4 \\
\hline 49 & $\begin{array}{l}\text { Derville et al. } \\
\text { (2018a) }\end{array}$ & $\begin{array}{l}\text { Study the behavior } \\
\text { of different } \\
\text { humpback whale } \\
\text { social groups }\end{array}$ & $\begin{array}{l}\text { Other ecosystems } \\
\text { Ecology }\end{array}$ & $\begin{array}{l}\text { New } \\
\text { Caledonia }\end{array}$ & REEF $=1$ \\
\hline 50 & $\begin{array}{l}\text { Derville et al. } \\
(2018 b)\end{array}$ & $\begin{array}{l}\text { Predict humpback } \\
\text { whale distribution } \\
\text { from various data } \\
\text { sources, including } \\
\text { crowd sourced } \\
\text { sightings data and } \\
\text { reef position }\end{array}$ & $\begin{array}{l}\text { Other ecosys } \\
\text { Ecology }\end{array}$ & $\begin{array}{l}\text { New } \\
\text { Caledonia }\end{array}$ & $\mathrm{REEF}=1$ \\
\hline 51 & $\begin{array}{l}\text { Boussarie et } \\
\text { al. (2018) }\end{array}$ & $\begin{array}{l}\text { MCRMP used as } \\
\text { background map } \\
\text { for visualization of } \\
\text { field sites ani } \\
\text { statistics }\end{array}$ & Ecc or $\mathrm{y}$ & $\begin{array}{l}\text { New } \\
\text { Caledonia }\end{array}$ & REEF $=1$ \\
\hline 52 & $\begin{array}{l}\text { Cheok et al. } \\
(2018)\end{array}$ & $\begin{array}{l}\text { Assess the benetic } \\
\text { of updating mo } \\
\text { frequently arivual } \\
\text { priorities }{ }^{\prime} \text { CRMP } \\
\text { used to define } \\
\text { rarity of oral reef } \\
\text { clas }\end{array}$ & Conservation & Fiji & L3 \\
\hline 53 & $\begin{array}{l}\text { Feretti et al. } \\
(2018)\end{array}$ & $\begin{array}{l}\text { Es ima ion of the } \\
\text { ab ndance of shark } \\
\text { p rulations in } \\
\text { Chagos } \\
\text { Archipelagos }\end{array}$ & Ecology & UK & $\begin{array}{l}\text { Unclear, } \\
\text { REEF=1 } \\
\text { probably }\end{array}$ \\
\hline 54 & $\begin{array}{l}\text { Harborne et al. } \\
\text { (2018) }\end{array}$ & $\begin{array}{l}\text { Estimate fish } \\
\text { biomass and } \\
\text { fishing pressure to } \\
\text { guide management }\end{array}$ & Fishery & $\begin{array}{l}\text { Micronesia } \\
(5 \\
\text { countries })\end{array}$ & L4 \\
\hline 55 & $\begin{array}{l}\text { Miller et al. } \\
(2018)\end{array}$ & $\begin{array}{l}\text { MCRMP used as } \\
\text { background map } \\
\text { for visualization of } \\
\text { field sites and } \\
\text { statistics }\end{array}$ & Visualization & Fiji & L4 \\
\hline 56 & $\begin{array}{l}\text { Moritz et al. } \\
\text { (2018) }\end{array}$ & $\begin{array}{l}\text { MCRMP used as } \\
\text { background map } \\
\text { for visualization of }\end{array}$ & Visualization & $\begin{array}{l}\text { Pacific } \\
\text { Oceen }\end{array}$ & $\mathrm{REEF}=1$ \\
\hline
\end{tabular}




\begin{tabular}{|c|c|c|c|c|c|}
\hline & & $\begin{array}{l}\text { field sites and } \\
\text { statistics }\end{array}$ & & & \\
\hline 57 & $\begin{array}{l}\text { Pearse et al. } \\
(2018)\end{array}$ & $\begin{array}{l}\text { Assess the } \\
\text { vulnerability of } 2 \\
\text { reef fish species to } \\
\text { fishing pressure. } \\
\text { MCRMP used to } \\
\text { define habitat } \\
\text { preferences of } C \text {. } \\
\text { undulatus and } B . \\
\text { muricatum } \\
\text { (stratification of } \\
\text { surveys, and } \\
\text { generalization) }\end{array}$ & $\begin{array}{l}\text { Ecology } \\
\text { Fishery }\end{array}$ & $\begin{array}{l}\text { Solomon } \\
\text { Islands }\end{array}$ & L4 \\
\hline 58 & $\begin{array}{l}\text { Silver et al. } \\
(2019)\end{array}$ & $\begin{array}{l}\text { Predict where coral } \\
\text { reefs will provide } \\
\text { coastal protection } \\
\text { in the future } \\
\text { considering } \\
\text { different climate- } \\
\text { induced effects }\end{array}$ & Future reefs & Bahamas & Level 4 \\
\hline 59 & $\begin{array}{l}\text { Gairin and } \\
\text { Andréfouët } \\
(2020)\end{array}$ & $\begin{array}{l}\text { Sensitivity of Aichi } \\
\text { Biodiversity Target } \\
11 \text { scores to habita } \\
\text { definitions anc } \\
\text { MCRMP thematic } \\
\text { levels }\end{array}$ & Corse vation & $\begin{array}{l}\text { New } \\
\text { Caledonia }\end{array}$ & L1-5 \\
\hline 60 & Li et al. (2020) & 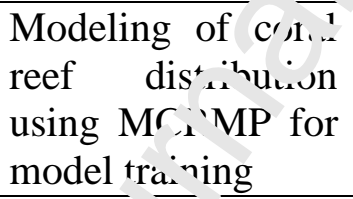 & Inventory & Global & L4 \\
\hline 61 & $\begin{array}{l}\text { Lyons et al. } \\
(2020)\end{array}$ & $\begin{array}{lr}\text { Presentali n } & \text { of } \\
\text { All_a Cural Atlas } \\
\text { pr duc s } \\
\text { co rparison and } \\
\text { M_RMP }\end{array}$ & Inventory & Global & L4 \\
\hline 62 & $\begin{array}{l}\text { Smallhornwest } \\
\text { et al. (2020) }\end{array}$ & $\begin{array}{l}\text { Presentation of a } \\
\text { multi-layer } \\
\text { database, including } \\
\text { habitat maps }\end{array}$ & Visualization & Tonga & L1-L5 \\
\hline
\end{tabular}

Table 2: SWOT analysis of the Millennium Coral Reef Mapping Products.

\begin{tabular}{|c|c|}
\hline Strengths & Weaknesses \\
\hline $\begin{array}{l}\text { - Global hierarchical geomorphological } \\
\text { classification } \\
\text { - Enhanced surface area of } \\
\text { geomorphological units and distance to } \\
\text { reef metric }\end{array}$ & $\begin{array}{l}\text { - Small patch structures are not detected due } \\
\text { to imagery satellite resolution } \\
\text { - Some coral reef configurations can be } \\
\text { interpreted differently } \\
\text { - Not all reef types have been documented }\end{array}$ \\
\hline
\end{tabular}


- High-resolution (1 ha) consistent map for - May need long training for some users to many regions worldwide understand the typology

- No need for ground-truth data to identify geomorphological classes

- High accuracy

- Lack of documentation that could foresee all applications and provide specific guidelines

- Several areas (e.g.,. Red Sea) are not completed

\section{Opportunities}

Threats

- Evaluation of modern coral reef surface areas

- Classification of reefs according to growth patterns

- Assessment of the influence of reef geomorphological structure on biodiversity patterns

- Evaluation of reef productivity

- Assessment of the influence of reef geomorphological structure on atoll lagoon functioning

- Planning for regional conservation

- Management of reef fisheries

- Climate change modelling

- Synergy with more detailed coraı reef mapping projects. Higher res $\mathrm{sl}_{\text {. }}^{\text {tion }}$ products can be nested withir the MCRMP typology (cf. Figur _) Can be extended with high level oi mapping, using higher resolution : mag :s $(<10 \mathrm{~m}$ resolution)

- Synergy with other ecusystems global mapping project 


\section{Declaration of competing interests}

$\bigotimes$ The authors declare that they have no known competing financial interests or personal relationships that could have appeared to influence the work reported in this paper.

$\square$ The authors declare the following financial interests/personal relationships which may be considered as potential competing interests: 
Graphical abstract

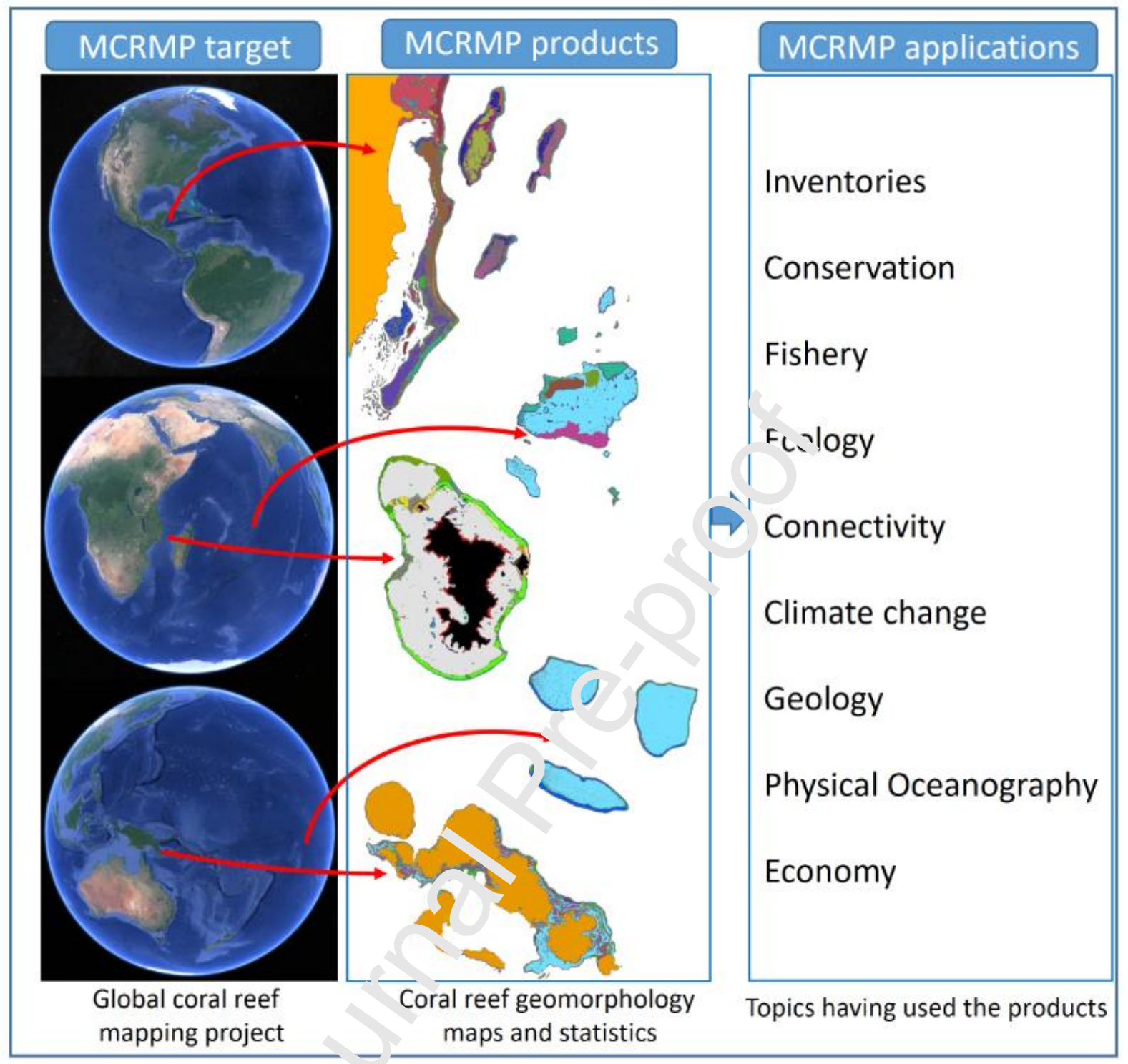




\section{Highlights}

The impact of the Millennium Coral Reef Mapping Project (MCRMP) is reviewed It was the first remote sensing project that targeted coral reefs globally MCRMP has created since 2004 hierarchical maps of coral reefs worldwide using Landsat Examples of inventories, conservation, fishery, climate and ecology applications are discussed

Lessons from MCRMP can be useful for future global projects 